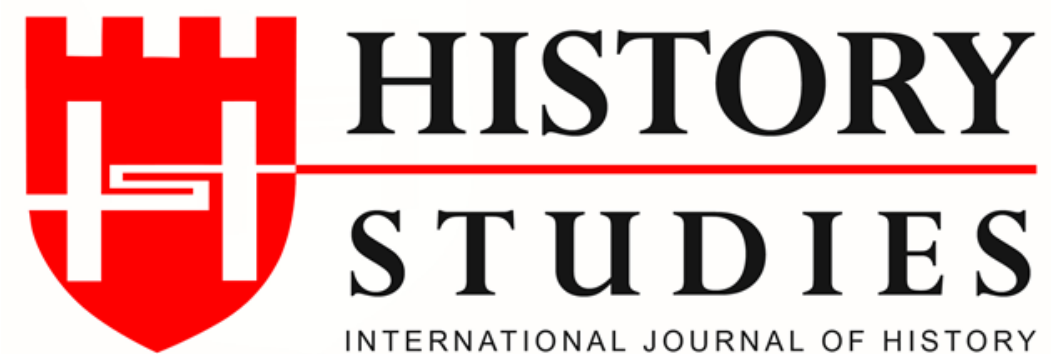

ISSN: 13094173 / (Online) 1309 - 4688 (Print)

Volume: 13, Issue: 4, August 2021

www.historystudies.net

\title{
BİZANS-OSMANLI İLIŞKİLERINDE SÖZDE BARIŞ DÖNEMİ (1413-1421)
}

The Period of So-called Peace in Byzantine-Ottoman Relations (1413-1421)

\author{
Dr. Öğr. Üyesi Nilgün ELÂM \\ Anadolu Üniversitesi \\ nelam@anadolu.edu.tr \\ ORCID ID: 0000-0001-6966-4778
}

Makale Türü-Article Type

Geliș Tarihi-Received Date

Kabul Tarihi-Accepted Date

DOI Number
Araştırma Makalesi-Research Article 07.05.2021

20.08.2021

10.9737/hist.2021.1032

Atıf-Citation: $\quad$ Nilgün Elâm, “Bizans-Osmanlı İlişkilerinde Sözde Barış Dönemi (1413-1421)", History Studies, 13/4, Ağustos 2021, s. 1205-1237. 

HISTORY STUDIES

Uluslararası Tarih Araştırmaları Dergisi International Journal of History 13/4, Ağustos - August 2021

1205-1237

Araştırma Makalesi

\section{BİZANS-OSMANLI İLIŞKKILERINNDE SÖZDE BARIŞ DÖNEMİ (1413-1421)}

The Period of So-called Peace in Byzantine-Ottoman Relations (1413-1421)

\section{Dr. Öğr. Üyesi Nilgün ELÂM}

\section{$\ddot{O} z$}

Osmanlı saray vakanüvistlerinin eserleri, Sultan I. Mehmed'in (1413-1421) saltanatı döneminde Bizans imparatoru II. Manuil Palaiologos (1391-1425) ile kurduğu diplomatik ilişkilerin mahiyeti üzerine detaylı bilgiler vermekten uzaktır. Oysaki imparator, Ankara Savaşı (28 Temmuz 1402) öncesindeki gibi hem Anadolu'ya hem de Rumeli'ye hâkim olmanın mücadelesi veren Osmanlı sultanının karşısında bunu engellemek adına güç birliği yapan Anadolu Türk beylikleri ve Balkanlı Hristiyan devletlerinin eşgüdümlü faaliyetlerinde bir çok kez kilit rol oynadı. İmparatorun müttefikleri Karamanoğlu II. Mehmed Bey (?-1423) ve Candaroğlu İsfendiyar Bey (13921440) gibi Anadolu'daki Türk beyleri, Sırp despotu Stefan Lazareviç ve Vlah voyvodası Mircea idi. Dukas, Sphrantzes, Halkokondyles, Kritovulos gibi Bizansl tarihçilerin kronikleri, Anonim Grekçe Kısa Kronikler, II. Manuil'in mektupları, Filozof Konstantin'in Stefan Lazareviç biyografisi, Burgundiyalı elçi Ghillebert de Lannoy'un kayitları, Venedik ile Ragusa senato kararlarının bilgileri ile birleştirildiğinde bu ittifakın varlığ1 kendini hissettirmektedir. Söz konusu veriler, Fetret döneminde (1402-1413) bu ittifakın tek seferlik olmadığını, aksine Sultan I. Mehmed'in tahta çıkışı sonrasinda ve hatta Sultan II. Murad'ın (1421-1451) tahta çıkış sürecinde devreye girdiğini göstermektedir. Osmanlı kronikleri, bu güç odakları arasındaki bu bağ hakkında sessiz kaldıkları gibi aynı zamanda sultanların bunlara karşı yürüttükleri askeri operasyonları birbirinden bağımsız olaylarmış gibi sunmaktadır. Bu bakımdan yukarıda sözünü ettiğimiz kaynak grubu, Osmanlı kroniklerinin biraktığı boşlukları doldurması bakımından büyük öneme sahiptir. $\mathrm{Bu}$ makalenin amac1, Bizanslı, Türk ve
Ottoman chronicles, written by palace historians, are far from providing detailed information on the nature of the diplomatic relations that Sultan Mechmed I established with the Byzantine emperor Manuel II Palaiologos during his reign. However, the Byzantine emperor played repeatedly a key role in the coordinated activities of the Anatolian Turkish principalities and Balkan Christian states, who joined forces to prevent the Ottoman sultans, who struggled to dominate both Anatolia and Rumelia, as before the battle of Ankara. These actors accompanying the Emperor in this alliance were Turkish emirs in Anatolia such as Karamanoglu Mechmed II Beg (?-1423) and Candaroğlu İsfendiyar Beg (1392-1440), and Serbian prince Stephan Lazarevic in the Balkans and Vlah vojvoda Mircea. Chronicles written by Byzantine historians such as Ducas, Sphrantzes, Halkokondyles, and Anonymous Greek Short Chronicles, the epistles, Philosopher Constantine, Stephen Lazarevic's biographer, the records of the Burgundian diplomat Ghillebert de Lannoy, who had been sent as an ambassador to the Byzantine palace, the reports of Venetian ship-owners (operated in Levant) which are echoed in the Senatorial as well as of the Venetian representatives (bailos) in Constantinople and finally the records of Ragusan Senate, when combined, provide very important data on the existence of a multilateral alliance that reveals the coordinated activities of these forces. These data indicate that this alliance, which came into effect during the Fetret period, was not one-time; on the contrary, it was long enough to continue after Mechmed I's ascension to the throne and even during the process of Sultan Murad II (1421-1451) enthronement. Ottoman historians do not only remain silent about this bond between these powers but also present the military operations carried out by the sultans against them as independent events. In this respect, this group of sources mentioned above

\section{History Studies \\ www.historystudies.net}


Balkanlı müttefiklerin Osmanlı tarihinin 1413-1423 yılları arasında oynadıkları önemli rolü bu kaynakların verileri ışığında yeniden ele almaktır.

Anahtar kelimeler: Bizans Tarihi, Osmanlı Tarihi, I. Mehmed, II. Murad, II. Manuil Palaiologos, VIII. İoannis Palaiologos is of great importance in terms of filling the gaps left by Ottoman chronicles. The aim of this article is to revisit the crucial role played by the Byzantine, Turkish and Balkan allies in Ottoman history between 1413 1423 in the light of the information provided by these sources.

Keywords: Byzantine History, Ottoman History, Mechmed I, Murad II, Manuel II Palaiologus, John VIII Palaiologus

\title{
Giriş
}

Sultan I. Bayezid (1389-1402), hem Anadolu'da hem de Balkanlarda savaş yanlısı bir politika izleyerek bir imparatorluğa dönüştürmek istediği Osmanlı Devleti’nin sınırlarını genişletti. 1394 yılında Bizans başkentini kuşatma altına aldı, Mora'ya akınlar düzenledi ve Niğbolu'da Haçlı ordusu karşısında zafer kazandı. Bulgaristan ve Arnavutluk'u Osmanlı kontrolü altına aldı ve Vlah (Eflak) voyvodası Mircea'yı Tuna'nın kuzeyine püskürttü. Anadolu'da yürüttüğü askeri operasyonlarla Karaman Beyliği başta Türk beyliklerini ilhak etti ve Fırat boylarına kadarki Anadolu arazisini Osmanlı bayrağı altında birleștirdi. Osmanlı Devleti, I. Bayezid'in Ankara Savaşı'nda (28 Temmuz 1402) Timur'a (1370-1405) yenilerek esir düşmesi sonucunda parçalandı ve "Fetret Dönemi"ne girildi. Osmanlı kroniklerinden öğrendiğimiz kadarıyla Bayezid'in Emir Süleyman, İsa, Mehmed, Musa, Mustafa, Kasım adında altı şehzadesi ve Fatma Hatun adında bir kızı vardı. En büyük şehzadesi Ertuğrul, daha erken bir tarihte (19 Ağustos 1400) vefat etmişti. ${ }^{1}$ Sultanın Akşehir' de ölümü (9 Mart 1403), şehzadeler arasındaki iktidar kavgasını ateşledi. Veziri âzâm Çandarlı Ali Paşa başta devlet ricalinin tavsiyelerine uyan en büyük șehzade Emir Süleyman, II. Manuil Palaiologos (1391-1425), VII. İoannis Palaiologos (1399-1403), Balkanlar'daki ve Levant'daki (Yakındoğu) Hıristiyan hükümdarları ile Rumeli'deki akınc1 beylerinin desteğiyle 1403-1411 yılları arasında devletin Avrupa'daki kısmına egemen oldu. İsa Çelebi, Bursa'nın ve Anadolu kısmının kontrolü için kardeşi Mehmed Çelebi'ye karşı giriştiği mücadeleyi kaybetti ve Eskişehir'de öldürüldü. Mehmed Çelebi, kendisi gibi başta desteklediği Süleyman'ı saf dışı bırakmak isteyen Bizans imparatoru, Vlah voyvodası Mircea, Sırp preni Stefan Lazareviç, Karamanoğlu II. Mehmed Bey (?-1423) ve Candaroğlu İsfendiyar'ı (13921440) içine alan geniş bir müttefik grubunun ortak operasyonuyla Musa Çelebi'yi Karadeniz üzerinden Rumeli'ye geçirdi. Musa Çelebi, Rumeli'nin kontrolünü ele geçirdi. ${ }^{2}$ Fakat Süleyman'1 bertaraf ettikten sonra hem Mehmed Çelebi'den bağımsız hareket etmeye hem de Hristiyan devletlere karşı babasının savaş politikasını benimseyince müttefiklerinin desteğini kaybetti ve sadece iki y1l tahtta kalabildi (1411-1413). Buna rağmen Mehmed Çelebi’yi, iki kez mağlup eden

\footnotetext{
${ }^{1}$ Nicolae Jorga, Geschichte des Osmanichen Reiches, in Europa, C. I, Perthes, Gotha 1900, s. 234; Nicolae Jorga, Notes et extraits pour servir à l'histoire des croisades au XVe siècle (1453-1476), C. I, Ernest Leroux, Paris 1899, s. 102 (19 Ağustos 1400); Hippolyte Noiret, Documents inédits pour servir à l'histoire de la domination vénitienne en Crète de 1380 à 1485, Thorin et fils, Paris, 1892, s. 110-111; Freddy Thiriet, Regestes des deliberations du Senat de Venise concernant la Romanie Romanie (1400-1430), C. II, Mouton, Paris 1959, s. 988 (19 Ağustos 1400); Elizabeth A. Zachariadou, "Ertogrul bey, il sovrano di Theologo (Efes)", Atti della societa ligure di storia patria, nuova serie V (79), Fasc. I, Genoa 1965, s. 158. Barker, Venedik kayıtlarında Zalapi unvanıyla anılan şehzade genellikle Süleyman Çelebi olduğu için söz konusu kayıtta adı geçen Ertuğrul'un (“... Ertogrul fu lo Zalapi ...”) aslında Süleyman olması gerektiğini ileri sürmektedir. Bkz. John W. Barker, Manuel II Paleologus (1391-1425): A Study in Late Byzantine Statesmanship, Rutgers University Press, New Brunswick 1969, s. 212, not. 16.

2 Nilgün Elam, "Musa Çelebi'nin Rumeli’ye Geçişinde Hıristiyan Aktörlerin Rolü (1403-1410)," History Studies. International Journal of History Studies, C. III, S. 1 (2011), s. 83-111.
}

\author{
History Studies \\ www.historystudies.net
}


Musa Çelebi, 1413 yılındaki Çamurlu savaşında yenildi. Devletin Rumeli ve Anadolu'da arazisi Edirne'de tahta çıkan I. Mehmed'in (1413-1421) otoritesi altında yeniden birleştirilmiş oldu. Onun tahta çıkışıyla Osmanlı tarihinde yeni bir döneme girildi. ${ }^{3}$

I. Mehmed dönemine özellikle Bizans İmparatoru II. Manuil ile "dostane" ilişkiler damgasını vurdu. İmparatorun zafer kazanan genç sultanla temasa geçmesi uzun sürmedi. Bir elçisini Mehmed ile Çamurlu savaşından önce yaptığı anlaşmanın koşullarını hayata geçirmek üzere Bursa'daki saraya gönderdi. Sultanın II. Manuil'in ve Balkanlı hükümdarların elçileriyle barış görüşmeleri 1413 yılının sonuna kadar sürdü. Osmanlıların Ankara savaşı sonrasında içinde bulundukları koşullar hakkında ayrıntılı bilgi veren Dukas'a göre II. Manuil, gönderdiği heyetle genç sultana rakibi Musa ile son karşılaşmasında verdiği etkin desteği hatırlattı. Ayrıca, imzaladıkları sözleşmeyle verdiği sözleri yerine getirmesini ve Musa'nın ele geçirdiği eski Bizans topraklarını iade etmesini beklediğini bildirdi. Bizanslı elçiye olumlu davranan Mehmed, sözünü tuttu. "Karadeniz klyllarında kontrol ettiği kaleleri, Orta Yunanistan'daki Tesalya bölgesinde bulunan köyleri ve kaleleri içeren tüm toprakları ve Propontis (Marmara Denizi) kıyılarında (1403 Gelibolu Antlaşması uyarınca Bizans'a verilen) sahip olduğu tüm toprakları devredeceğini kabul ettiği" bir antlaşma yaptı. İmparatora iyi niyet beslediğinin iletilmesini istedi. II. Manuil'e "Baba, Romalıların (Bizanslıların) imparatoru" diye hitap etti. Ona bir oğulun babasına olduğu sadık gibi kalacağına" dair yemin etti. ${ }^{4}$

Dukas'a göre, Mehmed, aynı zamanda Vlah ve Bulgar vassalların, İoannina (Yanya) despotu Karolo Tokko'nun, Mora despotu I. Theodoros'un (1383-1407) ve Mora'daki Achaia Latin prensliğinin hâkimi Centurione Zacharias ile diğer Hristiyan liderlerin elçilerini barışçıl bir şekilde kabul etti. Bu hükümdarlarla barışı koruma arzusunu yineledi ve Hıristiyan destekçilerine yardımlarından dolayı minnettarlığını gösterdi. ${ }^{5}$ Musa'ya karşı başarısında önemli rol oynayan Stefan Lazarevic'i de unutmadı. Sırp despotuna Niş’teki (Naissos) Kaprian kalesini ve Znepolje bölgesini, Niş ile Sofya arasındaki toprakları verdi. ${ }^{6}$ Dukas, artık bağımsızlığını yitirmiş olan Bulgarların elçilik heyetinin de sultanın huzuruna çıktığını yazmaktadır. ${ }^{7}$

Geçmişte Osmanlı tehdidini hissetmiş bu devletlerin iç sorunlarını çözebilmek için Mehmed ile barış yapması şarttı. Böylece, Süleyman Çelebi zamanında olduğu gibi yeniden Osmanlılarla barış içindeydiler. Diğer yandan barış, I. Mehmed için de gerekliydi. Sultanın o sırada çok dikkatli

\footnotetext{
${ }^{3}$ Colin Imber, The Ottoman Empire 1300-1481, İsis, İstanbul, 1989, s. 73-75.

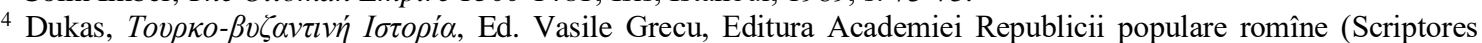
byzantine 1), Bucuresti, 1958, s. 133.7-18; Constantine Jirecek, Geschichte der Serben (1371-1537), C. II, A. Perthes, Gotha 1918, repr. Adolf M. Hakkert, 1967, s. 151; Imber, bu maddelerin Süleyman Çelebi ile Hiristiyan Levant dünyasının Hıristiyan güçleri arasında imzalanan Gelibolu Antlaşması'ndaki (1403) Bizans tekliflerinin onaylandığı yeni bir antlaşmanın varlığını kanıtladığını ileri sürmektedir. Bkz. Imber, age, s. 76; Antlaşmanın orijinal metni kayıptır. Bkz. Franz Dölger, Regesten der Kaiserurkunden des oströmischen Reiches von 565-1453, C. V, C. H. Beck, München, 1965, s. 98, no. 3334 ve no. 3332; Ayrica bkz. Barker, Manuel II, s. 288-289; David Balfour, Politico-historical works of Symeon. Politico-Historical Works of Symeon, Archbishop of Thessalonica (1416/17 to 1429), Österreichische Akademie der Wissenschaften, Vienna, 1979, s. 126.

5 Dukas, s. 133.19-25; Kenneth M. Setton, The Papacy and the Levant (1204-1571), C. II, American Philosophical Society, Philadelphia, 1978, s. 6.

${ }^{6}$ Sirp despot Stefan Lazareviç'in biyografi yazarı Filozof Konstantin'e göre, bu elçilik heyeti Stefan tarafından Mehmed'e gönderildi. Sultan, müzakereler sonucunda despota Çuprijan kalesi ve Vranje ile Sofya arasındaki bölgeleri bıraktı. Mehmed ile Stefan arasındaki barış, Ragusa'dan gelen 1414, 1415 ve 1416 yıllarına ait üç mektup tarafından da doğrulanmaktadır. Bkz. Stanoje Stanojevic, "Die Biographie Stefan Lazarević's von Konstantin dem Philosophen als Geschichtsquelle,” Archiv für Slavische Philologie, C. XVIII (1896), s. 453; Imber, Dukas'1n Sirp elçilik heyetine atıfta bulunmasının gerçek gibi göründüğüne dikkat çekmektedir, çünkü Filozof Konstantin de iki taraf arasındaki 1413 ve sonrasında barışla sonuçlanan diplomatik ilişkilere atıfta bulunmaktadır. Bkz. Imber, age, s. 76; Ayrıca bkz. Jirecek, age, s. 151; Nedim Filipovič, Princ Musa i Sejh Bedreddin, Svjetlost, Sarajevo, 1971, s. 510, not. 710 .

${ }^{7}$ Imber, Dukas'ın Bulgar elçilik heyetine ilişkin anlatısının Bizanslı tarihçinin olaylar hakkında sadece varsayımlar yaptığını gösterdiğine inanmaktadır. Bkz. Imber, age, s. 76.
}

\author{
History Studies \\ www.historystudies.net
}


olması ve bu güçlerle çatışmadan kaçınması gerekiyordu, çünkü ne Anadolu'da ne de Balkanlar'daki iktidarını henüz tam olarak sağlamlaştıramamıştı. Osmanlı Devleti'nin Fetret devri sırasında Anadolu'da yitirdiği üstünlüğünü ve birliğini yeniden sağlamak zorunda idi. Hristiyan elçiler Bursa'dayken Venedik ve Levant dünyasındaki Venedik devletçiklerinin elçileri de geldi. Ancak, Venediklilerin barış umutları tüm çabalarına rağmen gerçekleşmedi. Mehmed'in Venediklilere karșı tavrı olumsuzdu ve bu nedenle iki taraf arasındaki ilișkiler uzun süre barıș anlaşmasına varılamadan gergin kald1. ${ }^{8}$ Osmanlı iç savaşı boyunca Venedik, kontrolünü Epiros, Arnavutluk ve Mora'ya kadar geniş̧letmeyi başarmıştı. Venedik, sonuçsuz kalan barış görüşmeleri yüzünden Osmanlılarla Bizanslılardan bağımsız bir antlaşma yapmaya çalıştı. Venedik Senatosu, Haziran 1414'te Konstantinopolis'teki balyozu (temsilcisi) Francesco Foscarini'ye, Musa Çelebi ile imzalanan anlaşmanın yenilenmesini sağlamasını emretti. Ek olarak elçi, Arnavutluk'taki Venedik mülkleri üzerindeki verginin kaldırılması için müzakerelerde bulunmalıydı. Diğer görevi, Menteşe ve Aydın beyliklerini Mehmed ile bir antlaşma yapmaya ve olası vassallık koşullarının yenilenmesine teşvik etmekti. Venedik, sultanın bu beyliklerin Venedik gemilerine saldırılarını önleyeceğini ummaktaydı. ${ }^{9}$ Nevar ki Mehmed'in o sırada öncelik verdiği başka meseleler söz konusuydu. Mora'da dostane seyreden Osmanlı-Bizans ilişkilerini bozacak başka gelişmeler yaşanmak üzere idi.

HISTORY STUDIES

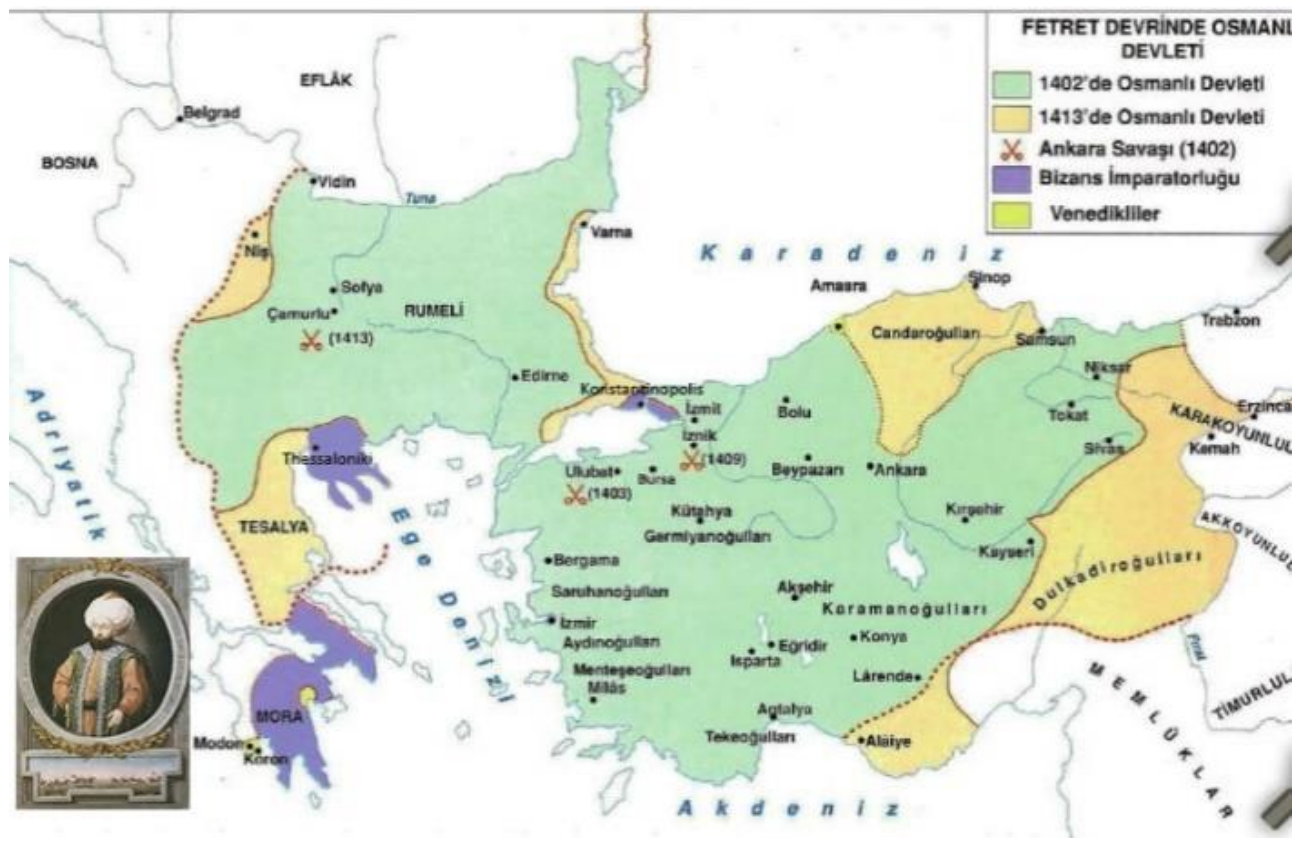

https://www.eokultv.com/1-mehmet-celebi-donemi-1413-1421/5102 Alınt1 Tarihi: 18.8.2021 Harita düzenleme: Rüveyda Ceylan

\footnotetext{
${ }^{8}$ Setton, age, s. 6.

${ }^{9}$ Imber, age, s. 76-77.
} 


\title{
1) Bizans- Osmanlı İlişsilerindeki Gerilim Dönemi (1414-1416)
}

İmparator II. Manuil, Sultan I. Mehmed ile yaptığı barışa rağmen, Venedik-Osmanlı anlaşmazlığından yararlanmak ve Venediklileri Osmanlılara karşı bir Haçlı Seferi düzenlemeye teşvik etmek istedi. Bu nedenle 1413 yılının sonunda maddî destek elde etmek için Venedik'e bir elçi heyeti gönderdi. Ancak, tüm çabalarına rağmen başarısız oldu. Ocak 1414'te Venedik Senatosu, diğer Hıristiyan hükümdarların Bizans'a yardım etmeleri halinde onlara katılacağını bildirdi. ${ }^{10} \mathrm{Bu}$ arada Euboia (Eğriboz) adasındaki Venedik arazisi Gelibolu'daki Osmanlı donanmasının hücumuna uğradı. ${ }^{11}$ II. Manuil, Venedik ile diplomatik temasların yanında Balkan yarımadasındaki topraklarını güvenceye almak için ek önlemler almaya karar verdi. 25 Temmuz 1414 tarihinde Konstantinopolis'ten Mora'daki Bizans despotluk arazisine yelken açtı. ${ }^{12}$ Ama önce yeniden Bizans egemenliğine soktuğu Thasos (Taşoz) adasına uğradı. ${ }^{13}$ Eylül ayında Thessaloniki'ye (Selanik) yöneldi. ${ }^{14} 28$ Kasım 1414'te kente ulaştı. ${ }^{15}$ Tüm zamanını kent ile Aynaroz manastırlarının talep ve ihtiyaçları gibi meselelere verdi. Thessaloniki'nin idaresini oğlu Andronikos'a (1408-1423) emanet etti. ${ }^{16} 1415$ kışının sonunda Mora'ya doğru yola çıktı. ${ }^{17}$ Venedik kontrolündeki Euboia (Eğriboz) adasında konakladı. ${ }^{18}$ Sphrantzes ve Anonim Grekçe bir kısa kroniğe göre Venedik balyozu tarafından karşılanıp ağırlandı. 29 Mart 1415'te Mora'ya ulaştı. Korinthos berzahından 4-5 km uzaklıktaki Saronikos Körfezi'ndeki Kechreon limanına demirledi. Bu ziyaretin amac1, önceki Mora ziyaretinden (1408) beri istediği bir şeydi: Osmanlı akınlarına karşı Heksamilion (Germehisar) surunu tamir etmek. ${ }^{19}$ O sırada Mora Despotu imparatorun oğlu II. Theodoros (1407-1443) idi. Osmanlı akıncılarının saldırılarıyla zayıflayan despotluğun güvenliğini arttırmak isteyen imparator, 1415 yılının Nisan ayında surun tamiri için emir verdi. Manuil, surları yirmi beş gün içinde ayağa kaldırarak 153 kule ve iki kaleyle güçlendirdi. ${ }^{20} \mathrm{Bu}$ faaliyet, imparatorun bir mektubunda anlattı̆̆ 1 üzere, başta şehzade Murad

${ }^{10}$ Imber, age, s. 76-77.

${ }^{11}$ Venedik filosunun saldırısı için bkz. age, s. 76-77; İnalcık, Bizans ile Venedik arasındaki temasların Osmanlıları rahatsız ettiğine dikkat çekmektedir. Ege'de artış gösteren Osmanlı korsanlık faaliyetleri bu ilişkiler 1şığında değerlendirilmelidir. Bkz. Halil İnalcık, "Mehemmed I" Encyclopedia of Islam, $2^{\text {nd }}$ ed., C. VI (1991), s. 975-978.

${ }^{12}$ Sphrantzes, Manuil'in yolculuğunu yanlışlıkla 1413 yılına tarihlemektedir. Bkz. Sphrantzes, Chronicon Minus, Ed. Paul Migne, Patrologia Graeca, C. CLVI, s. 1026B. 1414'teki olayın kronolojisi hakkındaki tartışma için bkz. Barker, age, 298, not. 9; Raymond J. Loenertz, "Epître de Manuel II Paléologue aux moines David et Damien en 1416”, Studi bizantini e neoellenici, C. IX (1957), s. 204-296.

${ }^{13}$ Manuil’in Thasos (Taşoz) adasındaki faaliyetleri için bkz. Barker, age, s. 299, not. 10 ve 11.

${ }^{14}$ Sphrantzes, s. 1026B; Barker, age, s. 300.

15 Manuil'in Thessaloniki'ye gelişinin tarihi Aragon kralına yazdığı ve Thasos adasındaki faaliyetlerinden bahseden bir mektubu sayesinde tarihlenebilmektedir. Bkz. Dölger, age, no. 3343; Mektup için bkz. Barker, age, s. 333-334; Ayrica bkz. Loenertz, agm, s. 296.

${ }^{16}$ İmparatorun Aynaroz manastırlarına yaptığı bağışlar ve ilgili bibliyografya için bkz. Barker, age, 301, not. 14.

${ }^{17}$ Manuil'in Mora'ya gidişi, Aynaroz'dan iki keşişe yazdığı bir mektupta konu edilmektedir. Bkz. Barker, age, s. 301 302-308 ve not. 15 .

18 İmparatorun Euboia'da konaklaması, Venedik senatosu kararlarında konu edilmektedir. Bkz. Barker, age, s. 310 , not. 16; Dionysios A. Zakythenos, Le despotat grec de Morée, Société d'édition "Les Belles Lettres," C. I, Paris, 1932, repr. Variorum London 1975, s. 168; Venedik'in imparatorun Mora yolculuğu ile ilgili endişeleri için bkz. Thiriet, Régestes, no. 1578, s. 135; Ayrica bkz. William Miller, The Latins in the Levant. A History of Frankish Greece (1204-1566), John Murray, London 1908, 377; Zakythenos, age, s. 171-172.

${ }^{19}$ Sphrantzes, s. 1026B “(Manuil), 6923 dünya yılında (1413) Kechreon adlı limanda karaya çıktı ve Nisan ayında Heksamilion'u yeniden inşa etmek için geldi."; Halkokondyles, C. I, s. 173.4-14; Barker, age, 277-278. Heksamilion suru için ayrica bkz. Barker, age, 311, not. 19.

${ }^{20}$ Peter Schreiner, Die byzantinischen Kleinkroniken, C. I, Österreichischen Akademie der Wissenschaften, Wien 1975, Anonim Grekçe Kisa Kronik, no. 32, paragraf 33, s. 234: "[6923 dünya yılının 8. indiksiyonunda (29 Mart - Mayıs) Imparator Manuil geldi ve Heksamilion surunu inşa etti]."; Anonim Grekçe Kısa Kronik, no. 33, paragraf 26, 246247: “ [6923 dünya yılının 8. indiksiyonun (29 Mart-2 Mayıs) Imparator Kyr (Efendi) Manuil, Heksamilion surunu inşa etmeye başladı. 6923 dünya yllında Imparator Manuil Palaiologos (Mart ayının 12 'sinde Büyük Cumartesi günü) geldi ve Mayıs ayında Heksamilion 'u inşa etti.]"; Anonim Kronik, no. 35, paragraf 6, s. 286: "6923 dünya yıll, 8. indiksiyonunda, 29 Mart'ta, Büyük Cuma günü, Imparator, merhum Efendi Manuil, Kechreai limanına geldi. Ve Nisan'in 8'inde Heksamilion'u temizlemeye ve yeniden inşa etmeye başladı ki orası 3800 kulaç uzunluğundayd.

\author{
History Studies \\ www.historystudies.net
}


olmak üzere Osmanlı tarafının sert tepkilerine neden oldu. Ancak, imparatorun yazdığı üzere, Murad, babasının vaktiyle ettiği yemini bozmaya cesaret edemedi. ${ }^{21} \mathrm{Bu}$ süre zarfında, II. Manuil, Venedik ile temasa geçti. Amacı, Osmanlılara karşı malzeme yardımı ve askerî takviye sağlamaktı. Ancak Venedik, surun Hıristiyanların çıkarları açısından önemine işaret etderek inşaat için onu tebrik etmekle yetindi. İmparatora, destek anlamında yalnızca oğullarıyla birlikte Bizans başkentiyle Mora arasındaki ulaşımını sağlamak için yardım etmeyi teklif etti. ${ }^{22}$ Temsilcilerine, Osmanlıların yeniden inşa edilen sura saldırmaları durumunda Bizanslılara yardım etmelerini emretti. ${ }^{23}$

Manuil, Mora savunması için sadece Heksamilion suruna bel bağlamamıştı. 1414 yılından beri Venedik ile temaslarına ek olarak, 1416 yılında Doğu-Batı Kiliselerini birleştirme vaadiyle Haçlı seferi düzenlenmesini sağlamak amaciyla Constance Konsili'ne (1414-1418) de temsilciler göndermişti. ${ }^{24}$ Bir mektubunda Batıdan yardım gelene kadar "canavar düşman" olarak nitelendirdiği Mehmed'in karşısında yapayalnız olduğunu kaydeden imparator, inşaat masrafları için despotluk arazisinin ahalisine vergi uygulamak zorunda kaldı. Bir mektubunda yarımadadaki Bizanslı ahalinin bir kısmının Venedik arazisine kaçtığını yazan imparator, Venedikli yetkililerden kaçakların iadesini istediğinden bahsetmektedir. ${ }^{25}$ Manuil, surun güvenliğini müteveffa kardeşi I. Theodoros'un vaktiyle bölgeye yerleştirdiği "savaşç" Arnavutlara emanet etmek zorunda kaldı. ${ }^{26}$ Surun savunması dışında başka problemlerle de karşı karşıya kaldı. Heksamilion'un yeniden inşasına maddi olarak katılmak istemeyen Moralı arhontlar, imparatora tepki göstermişlerdi. ${ }^{27}$ Bu yerel güçler, Konstantinopolis merkezli daha istikrarlı bir yönetime tabi olmayı reddetmekteydi. Sonunda isyan ettiklerinde, imparator, liderlerinden bazılarını tutuklattı. Anonim Grekçe bir kısa kroniğe göre, arhontların çoğu 15 Temmuz 1415'teki savaşta ezici şekilde yenildi. Bir kısmının toprakları kısmen işgal edildi. Liderlerinin kontrolündeki Mantineia

Onun üstüne 153 kule dikti. ”; Anonim Grekçe Kisa Kronik, no. 36, paragraf 13, s. 292: “ (Bin dört yüz on dört yıllnda Imparator Kyr (Efendi) Manolis (Manuil) geldi ve Heksamilion'u inşa etmeye başladı).”; Anonim Grekçe Kisa Kronik, no. 40, paragraf 1, s. 314: "6923 yıll, 8. Indiksiyonda, 29 Mart'ta, Büyük Cuma günü [Megali Paraskevi], Imparator, Efendi Manuel, Kechreai limanına geldi. Ve Nisan'in 8 'inde Heksamilion'u temizlemeye ve yeniden inşa etmeye başladı ki orası 3800 kulaç uzunluğundaydı.)"; Anonim Grekçe Kısa Kronik, no. 42, paragraf 5, s. 321: "[6923 yllında Imparator Efendi Manolis (Manuil) geldi ve Heksamilion'u inșa etti]”; Sphrantzes, sur inşaatını 8 Nisan'a tarihlemektedir. Bkz. Sphrantzes, s. 1026B; Halkokondyles, imparatorun Mora despotluğuna bu ziyaretini 1408 yılında yaptığı ziyaretle karıştırmaktadır. Bkz. Laonici Chalcocandylae Historiarum demonstrationes, C. I, Ed. Jenö Darkó, Editiones criticae scriptorum graecorum et romanorum, Budapest, 1922, s. 172-173; Dukas, surun inşasından haberi olmayan ya da görmezden gelen tek Bizanslı tarihçidir. Bkz. Dukas, s. 139. Bir Venedik belgesi, inşaatın tamamlanmasını 28 Mart 1415'e tarihlemektedir. Jorga, Notes et extraits, s. 232-233, not. 1; Barker, bu tarihi olasılık dışı görmektedir. Bkz. John W. Barker, "On the Chronology of the Activities of Manuel II Palaeologus in the Peloponnesus in 1415" Byzantinische Zeitschrift, C. LV (1962), s. 48-55. Anonim kroniklerle Bizanslı tarihçilerin anlatıları hakkındaki yorumu için bkz. Peter Schreiner, Die Byzantinische Kleinchroniken. Kommentar, C. II, Wien, 1977, s. 402-403; Anonim Kronikler, Şahin Kılıç tarafından hazırlanan doktora tezinde tarihsel önemleri bakımından değerlendirilerek dilimize çevrilmiştir. Bkz. Şahin Kılıç, Bizans Kısa Kronikleri. Osmanlı Tarihinin Bizanslı Tanıkları, (Ankara Üniversitesi, Sosyal Bilimler Enstitüsü Yayımlanmamış Doktora Tezi), Ankara, 2011, s. 270, 281, 283, 286, 288, 303, 305, 315, 317, 318.

${ }^{21}$ Manuil'in (keşiş David ve Damianos) sur yapımına Osmanlı tepkisini anlatan mektubu için bkz. Barker, Manuel II, s. 213-217.

${ }^{22}$ Dölger, age, no. 3351, s. 102; Jorga, Geschichte, s. 372; Thiriet, age, no. 1583, s. 136; Barker, age, s. 314, not. 23.

${ }^{23}$ Thiriet, age, no. 1583, s. 136; Olası bir Osmanlı tehdidinin önemi hakkında bkz. Barker, age, s. 318-319.

${ }^{24}$ Thiriet, age, no. 1592; Barker, age, s. 290-353.

${ }^{25}$ Dölger, age, no. 3352; Jorga, Notes et extraits, s. 239-240; Thiriet, age, no. 1592, s. 138.

${ }^{26}$ Mektup hakkında bkz. Loenertz, "Epître", s. 299-304; Barker, age, s. 302-308; Zakythenos, age, s. 131; Miller, age, s. 367.

${ }^{27}$ Loenertz, agm, 295; Zakythenos, age, s. 170. Mektubun İngilizceye çevirisi için bkz. Barker, agm, s. 51-52.

\author{
History Studies \\ www.historystudies.net
}


kalesi ele geçirildi. ${ }^{28}$ İmparator, Mora'daki Bizans yönetimini güvenceye aldıktan sonra idareyi oğluna bırakarak Konstantinopolis'e döndü (Mart 1416). ${ }^{29}$

Manuil'in Mora'yı ziyaretinin amacı iki yönlü idi. Başlangıçta iç işleriyle ilgiliydi, ancak esas olarak bir șeye odaklanmıștı: buradaki Bizans topraklarını dıș tehditlerden korumak. İmparator, Sultan Mehmed ve onun "öfkeli" taraftarlarından korunmaya çalışıyordu. Buraya kadarki gelişmeler göstermektedir ki sultan ile imparator arasındaki barışçıl ilişkiler yüzeyseldi. Osmanlılar, Bizans topraklarına karşı savaş politikaları gütmekteydi. Manuil ve Venedik, Osmanlıların Heksamilion'u yok etmeye yönelik saldırılarını büyük olasılıkla öngörmüşlerdi. İmparator, bir mektubunda yazdığı üzere, inşaatı bitirebileceğine inanmadığı için sur projesine başta karşı koymayan sultanın asıl planını biliyordu. Gerçekten Mehmed, daha sonra Manuil'e karşı bir cezalandırma harekâtına girişti. ${ }^{30}$ Mektuptan anlaşıldığına göre, Manuil, surun inşasını üstlendiğinde karşılaşacağı tehlikenin farkındaydı. Ama bu çabanın Mora'nın güvenliği açısından anlamını da biliyordu. Bunun Osmanlıları rahatsız edeceğini bile bile Mehmed ile olan barış anlaşmasını riske atmayı göze aldı. Manuil, Osmanlı hedeflerinin hep aynı olduğunu, barışa rağmen kendi çıkarlarına hizmet ettiği takdirde eski düşmanca siyasetlerini uygulamaktan çekinmeyeceklerini biliyordu. Bu açıdan Mehmed ile kalıcı ve güvenilir bir barış bekleyemezdi. $\mathrm{Bu}$ nedenle, barıșın "resmen" bozulmaması yararınaydı; bunu açıkça zaman kazanmanın ve felaketten kaçınmanın bir aracı olarak benimserken, aynı zamanda imparatorluğu güçlendirmek için elinden gelen her şeyi yapmaya çalışıyordu. Elbette Mehmed de intikam peşinde koştuysa da bahanelerini saklamayı seçti. Manuil'in mektubuna bakılırsa, sultan Gelibolu'dan ayrılarak Mora'dan başkentine dönmekte olan imparatorla buluştu. Dukas'a göre Manuil, Konstantinopolis'e gitmeden önce sultanı gemisinde sıcak bir şekilde karşıladı. ${ }^{31}$ Bu konudan aşağıda ayrıntılı olarak bahsedilecektir. Mehmed ile bu yüzeysel dostluğun Manuil'e zaman kazandırdığına ve destek aramasına izin verdiğini kabul etmeliyiz. Manuil, geçmişteki Batı'daki diplomatik çabaların neden olduğu hayal kırıklığına rağmen, ${ }^{32}$ şüphesiz Mehmed'i gerçek

\footnotetext{
${ }^{28}$ Anonim Grekçe Kisa Kronik no. 33, paragraf 26, s. 246: “1415/6923, 8. indiksiyon, 29 Mart-2 Mayıs 26 (D) 6923 yılında İmparator Efendi Manuel Heksamilion'u inşa etmeye başladı”; Anonim Grekçe Kısa Kronik no. 33, paragraf 27, s. 246-247: “[ve II. Manuil, Moralı arhontlarl yakaladl, 15 Temmuz'da ve (30 Mart'ta, Büyük Cumartesi günü) Mora'nın arhontlarını tutukladı]"; Halkokondyles, s. 173; Dimitrios Chrysoloras tarafından yazılmış konuyla ilgili

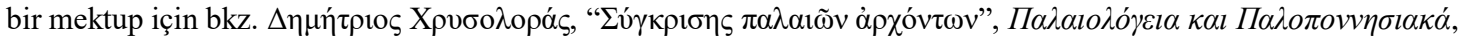

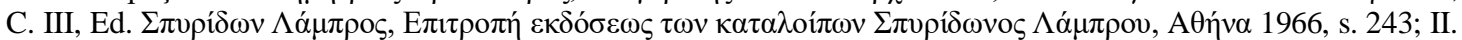
Manuil'in Aynarozlu keşişlere (David ve Damianos) yazdığı mektup için ayrıca bkz. George Dennis, The Letters of Manuel Palaeologus, Dumbarton Oaks Research Library and Collection, Washington, 1977, s. 213-217; Eliavurkos

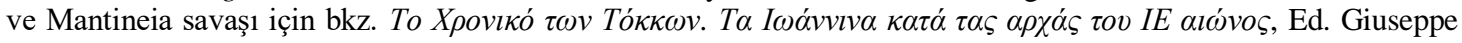

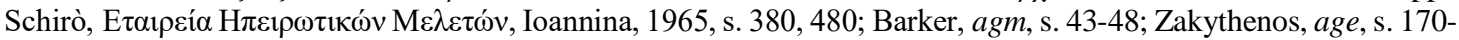
171; Loenertz, agm, 294-304; Raymond J. Loenertz, "Pour histoire du Peloponnese au XIVe siècle (1382-1404)" Revue des Etudes Byzantines, 1 (1943), s. 157; Barker, age, s. 310, not. 17; İmparatorun kaleminden çıkan bir mektup, bu bilgileri doğrulamaktadır. Bkz. Dennis, age, s. 218.

${ }^{29}$ Tarih, Sphrantzes tarafindan verilmektedir. Bkz. Sphrantzes, s. 1026C; II. Manuil, Aragon kralı I. Ferdinand'a yazdığ mektupta tarihten (25 Mart 1416) bahsetmektedir. Mektup için bkz. Barker, age, s. 334; Dennis, age, s. 216.

30 Jorga, Mehmed'in Heksamilion surunu inşaatının intikamını almak için Manuil'e karşı deniz hazırlıklarından bahseden bir Venedik kaynağına atıfta bulunmaktadır. Bkz. Jorga, Notes et extraits, s. 233, not. 2; Bu raporun doğru olup olmadığını tespit etmek (özellikle de Türk donanmasının birkaç ay sonra Venedikliler ile bir savaşa karışmadığı göz önüne alınırsa) zordur. Bkz. Barker, age, s. 318-319 ve 336, not. 72.

${ }^{31}$ Dukas, bu olayı anlatan tek kaynaktır. Dukas, s. 139; Barker, Manuil'in Mora ziyaretinin geri kalanı ile ilgili kısmın 1408 yılındaki önceki ziyaretiyle karıştırıldığını düşünmektedir. Ayrıca özellikle bu kısım da muhtemelen Manuil'in 1421 'de Mehmed ile daha sonraki görüşmesiyle karıştırılmıştır. Bkz. Barker, age, s. 320, not. 35, 351-352; Manuil'in sur yapımına ve Moralı archontların tavrına atıfta bulunarak şöyle devam eder: "Bu nedenle imparatorun Sultan Mehmed ile büyük sevgiye dayalı bir ilişkisi vardl." Barker, Mehmed' in Manuil'in Mora'daki faaliyetlerine tepkisinin açıkça bunun tersi olduğuna işaret etmektedir. Tarihçi, kroniğin bu açıklamasının Dukas tarafından sunulduğu üzere, 1416 yılında Manuil için muhtemelen bir dostluk işaretini yansıttığını düşünmektedir. Bu anlatı, modern tarihçiler tarafindan doğru kabul edilmektedir. Bkz. Jorga, Geschichte, s. 373; Edwin Pears, The Destruction of the Greek Empire and the Story of the Capture of Constantinople by the Turks, Longmans, Green and co., London 1903, s. 151.

${ }^{32}$ II. Manuil'in Batı'daki temasları için bkz. Barker, age, s. 320-338.
}

\author{
History Studies \\ www.historystudies.net
}


düşmanı olarak gördügünden Batıdan yardım gelene kadar onunla bir süreliğine ikiyüzlü bir barış ve sözde dostluğu sürdürmek zorundaydı. ${ }^{33}$ Osmanlılar da Heksamilion surunun inşasını düşmanca bir eylem olarak görseler de ${ }^{34}$ aktif bir şekilde harekete geçemediler. Sadece Bizans'in bölgedeki düşmanlarını kışkırtmakla yetindiler. Diğer durumlarda olduğu gibi Mora'daki Bizans karşıtı güç odaklarının bu duruşundan yararlandılar. Bunların en önemlisi, Achaia Latin Prensliği hâkimi Centurione Zaccharia idi. ${ }^{35}$ Mora despotluğundaki gelişmeler I. Mehmed'i meşgul eden tek sorun değildi. Anadolu'daki rakip Türk beyliklerine ve Ege sularında Venedikli hasımlarına karşı da bir mücadele vermek zorundaydı.

\title{
2) Sultan I. Mehmed'in Anadolu ve Ege'deki Varlık Mücadelesi
}

Yukarıda belirtildiği gibi, I. Mehmed'in II. Manuil ile askerî olarak karşı karşıya gelmemesinin nedeni, o sırada Anadolu'ya hâkim olmaya çalışıyor olmasıydı. Zira 1411-1413 yıllarında Mehmed'in Musa ile Rumeli'de savaştığı sırada yokluğundan faydalanan Anadolu Türk beyleri, konumlarını Osmanlılar aleyhine güçlendirme firsatı bulmuşlardı. Anadolu, Osmanlı sultanları için çok önemliydi, çünkü devletin insan gücünün kaynağıydı. Bu nedenle Mehmed, Hristiyan hükümdarlara gösterdiği barışçıl tavrı bu beyliklere karşı göstermedi. Hâkimiyetini sağlamlaştırmak ve Musa Çelebi'ye yardımlarından dolayı onları cezalandırmak için beyliklere karşı seferler düzenledi. Sonunda M. 1414 (H. 817) y1lında Batı Anadolu'nun tamamı sultana teslim oldu. Mehmed'in ilk hedefi İzmir'di. Bu konuda bilgi veren tek Bizans kaynağı olan Dukas'a göre Aydın'ın eski emiri Cüneyd, Osmanlı topraklarını ilhak ettiği için Mehmed'i kızdırmıştı. Cüneyd, Mehmed-Musa mücadelesi başlayınca Musa'nın tarafını tutmuştu. Ama onu savaş alanında bırakarak İzmir'e dönmüştü. Mehmed'in yokluğundan yararlanıp kent valisini idam etmiş ve eski Aydınoğlu beyliğini yeniden kurarak bağımsızlığını ilan etmişti. ${ }^{36}$ Cüneyd'in Ege'deki düşmanca faaliyetlerinden usanan Levant dünyasının Hıristiyan liderleri de Mehmed ile ittifak etmekte gecikmediler. Sonunda açıktan bir savaşa girişmeye cesaret edemeyen Cüneyd teslim oldu ve af diledi. Beyliğinin toprakları Osmanlı Devleti'ne ilhak edildi. ${ }^{37}$ Mehmed, bu askerî sefer (1414) sırasında Saint Jean Şövalyelerinin yeniden inşa etmeye başladığı İzmir kalesini yıktı. Menteşe beyi de Mehmed'in hâkimiyetini kabul etti. ${ }^{38}$ Mehmed, Batı Anadolu'daki zaferinin ardından Karaman Beyliği'nin genişlediği İç Anadolu'ya ilerledi. Karaman beyleri, geçmişten beri Osmanlı sultanlarının en tehlikeli düşmanları olduklarını kanıtlamışlardı. Karamanoğlu II. Mehmed, Fetret devrinin son safhasında diğer beylerle Osmanlı karşıtı ittifakın oluşmasında önemli bir rol oynamıştı. Mehmed, Rumeli'de Musa'ya karşı savaşırken şehzadeyle yaptığı barış antlaşmasını ihlal ederek Bursa kalesini kuşatmıştı. Kentin dış mahallelerini yağmalayarak büyük yıkıma yol açmış, ${ }^{39}$ dış

\footnotetext{
${ }^{33}$ Barker, bu anlaşmanın aslında bir ateşkesten başka bir şey olmadığını düşünmektedir, çünkü iki tarafın yegâne amacı birbirini yok etmekti. Barker, age, s. 339.

${ }^{34}$ İnalcık, Tuna nehrinin güneyindeki tüm köprülerin Osmanlı kontrolünde olmadığına işaret etmektedir. Bu nedenle Osmanlılar, Heksamilion inşaatını güvenlikleri için sürekli bir tehdit olarak gördüler ve ortadan kaldırmaya çalıştılar. Böylece, Osmanlı bakış açısından, imparator II. Manuil bu eylemiyle Mehmed ile imzaladığı barış antlaşmasını ihlal etmiş oluyordu. Bkz. Halil İnalcık, "Critica”, Archivum Ottomanicum, C. III (1971), s. 251-304.

${ }^{35}$ Ivan Djuric, Le Crépuscule de Byzance, Maisonneuve \& Larose, Paris, 1996, s. 172.

${ }^{36}$ Dukas, s. 115-19.

${ }^{37}$ Dukas, s. 147.1-5. Elizabeth A. Zachariadou, Trade and Crusade. Venetian Crete and the Emirates of Menteshe and Aydın (1300-1415), Instituto Ellenico, Venice, 1983, s. 88; Imber, bu seferi kronolojik olarak Karamanoğluyla yapılan barış sonrasına yerleştirmektedir. Bkz. Imber, age, s. 79 .

38 Uzunçarş1l1, agm, s. 501; Wittek, agm, s. 97; İnalc1k, "Mehemmed I", s. 975; Irene Melikoff, "Djunayd", Encyclopedia of Islam, $2^{\text {nd }}$ ed., C. 2 (1991), s. 599.

39 Âşıkpaşazâde, Tevârih-i Âl-i Osman, Âli Bey neşri, Matbaa-yı Âmire, İstanbul 1332, s. 151; Neşrî, Cihânnümâ, C. 2, Ed. Faik Reşit Unat-Mehmed Altay Köymen, Türk Tarih Kurumu Yayınları, Ankara 1995, s. 516-521; Oruç b. Âdil, Tevarih-i Âl-i Osman, Ed. Franz Babinger, Hannover 1925, s. 42; Hoca Sadeddin, Tacü 't-tevarih, C. II, Ed. İsmet Parmaksızoğlu, Başbakanlık Kültür Müsteşerlığı Kültür Yayınları, İstanbul 1974, s. 182; Müneccimbaş1, Camiü'd-düvel, Osmanlı Tarihi (1299-1481), Ed. Ahmet Ağırakça, İnsan Yayınları, İstanbul 1995, s. 174.
}

\author{
History Studies \\ www.historystudies.net
}


mahallelerindeki binaları ateşe vermişti. ${ }^{40}$ Âşıkpaşazâde'nin yazdığı üzere 1414/1415 yılında (H. 817/818) Mehmed, Karamanoğlunu cezalandırmak için ordusunu topladı. Kastamonu beyi İsfendiyar'dan yedek güçler istedi. ${ }^{41}$ Yakın zamanda teslim olan Germiyanoğlu'na müttefiki ve vassalı olarak ordusunu ikmal etmesi emrini verdi. ${ }^{42}$ Ordusuyla Seyitgazi üzerinden Akşehir'e yürüdü ve Konya'yı kuşattı. Karamanoğlu, yenilgiyi kabul etmek ve işgal ettiği toprakları iade etmek zorunda kald $1 .{ }^{43}$ Karamanoğlu, 1415 yılında Mehmed'e karşı yeniden isyan etti ve yeni bir operasyonla karşı karşıya kaldı. 1415 Şubatı'ndaki seferden önce Mehmed, olası bir dış müdahaleyi önlemek için Karamanoğlu'nun koruyucusu sayılan Mısır sultanına zengin hediyelerle elçiler gönderdi. Sonunda Mehmed, Karamanoğlu'nun birliklerini ikinci defa yendi ve Konya'yı kuşatt1 13 Mart-11 Nisan 1415 (H. Muharrem 818). Karamanoğlu ve oğlu Mustafa esir edildi. Hamid-ili ve Sa'id-ili gibi toprakları Osmanlı Devleti'ne ilhak edildi. ${ }^{44}$ Mehmed, Konya'yı kuşatmasına rağmen hava koşulları nedeniyle ele geçiremeyerek başkentini Mehmed Bey'e bıraktı. ${ }^{45}$ Bu davranışının nedeni, Neşrî’nin göstermeye çalıştığı gibi cömertliğinden ziyade Timur'un Anadolu'da kurduğu statüyü sürdürmek isteyen oğlu Şahruh'u kışkırtmak istememesinden dolayı idi. "Türklerin hükümdarının Karaman'a karşı savaştığını” ifade eden 28 Haziran 1415 tarihli Ragusa Senato kayd1, Mehmed'in bu seferini tarihlememize imkân sağlamaktadır. ${ }^{46}$

Mehmed, Karamanoğlu'nun arazisinden Candaroğlu'nun topraklarına yöneldi. Oradayken Karamanoğlunun kaybettiği toprakları geri almaya çalıştığını öğrenince geri döndü ve düşman ordusunu ikinci kez yendi. Karamanoğlu, oğlu Mustafa'yı Konya'da bırakarak tekrar kaçtı. Mehmed, Konya'yı kuşattı ama aniden hastalandı. Karamanoğlu, Bayezid Paşa tarafindan tutuklandı ve oğlu sultana teslim oldu. Paşa, sultanı Karaman beyini affetmeye ve 1415 'teki bir önceki antlaşmayla aynı koşullarda bir barış antlaşması yapmaya ikna etti. Antlaşmanın şartlarından biri de Karaman beyini I. Mehmed'in seferleri sırasında Osmanlı ordusuna takviye birlikler göndermek zorunda bırakıyordu. Karamanoğlu, Vlah ülkesine karşı yürüttüğü seferde Mehmed'e asker göndererek yükümlülügünü yerine getirdi. ${ }^{47} 1415$ olaylarının kronolojik kayıtlarından öğrendiğimize göre Mehmed, Karaman Beyliği'nin batısında Isparta çevresinde uzanan Hamidoğulları Beyliği'nin topraklarını ele geçirdi. Bursa-Ankara yolu üzerinde önemli bir kale olan Sivrihisar dâhil Beyşehir, Akşehir, Seydişehir'in güneyine kadar uzanan tüm alanı ele geçirdi. ${ }^{48}$ Böylece Mehmed, tüm iç engelleri aşarak yeniden Anadolu'nun efendisi oldu.

Anadolu fetihleri, Mehmed'in filosunun Ege Denizi'nde operasyonlar yapmasina izin verdi. Ne var ki I. Bayezid döneminde Gelibolu tersanesinin inşasıyla kurulan Osmanlı donanması, henüz Venediklilerle boy ölçüşebilecek güçte değildi. Yine de Andros adasının Venedikli hükümdarı Pietro Zeno'nun Osmanlı ticaret gemilerine karşı saldırgan tutumu Osmanlı

\footnotetext{
40 Âş1kpaşazâde, s. 151; Neşrî, s. 518-519; Hoca Sadeddin, Karamanoğlu'nun Bursa dışındaki binaların yıkılması emrini verdiğini yazmaktadır. Bkz. Hoca Sadeddin, s. 182; Lütfi Paşa, Karamanoğlu'nun Orhan Gazi zamanında inşa edilen caminin yıkılmasını emrettiğini yazmaktadır. Bkz. Lütfi Paşa, Tevârih-i Âl-i Osman, yay. M. Münir Aktepe, Türk Tarih Kurumu Yayınları, Ankara, 1993, s. 69, not. 1. Bayezid'in türbesi Mehmed'in tahta çıkışından önce tahrip edildiyse bu olay bu sırada olmuş olmalıdır.

41 Âşıkpaşazâde, s. 152; Neşrî, s. 530-31; Hoca Sadeddin, bu beye karşı herhangi bir saldırıdan bahsetmemekte, ancak Mehmed'in bu beyliği barış yoluyla ilhak ettiğini yazmaktadır. Bkz. Hoca Sadeddin, s. 184,

${ }^{42}$ Neşrî, Mehmed'in Germiyan, Candar ve Dulkadir beylerinden takviye birlikler istediğini yazmaktadır. Bkz. Neşrî, s. 516-34.

43 Âşıkpaşazâde, s. 153.

${ }^{44}$ Osman Turan, İstanbul'un Fethinden Önce Yazılmış Tarihi Takvimler, Türk Tarih Kurumu Yayınları, Ankara, 1984, s. 20, 56; Âşıkpaşazade, s. 153; Neşrî, s. 526-531. İnalcık, "Mehemmed I”, s. 975-978.

${ }^{45}$ Uzunçarş1lı, agm, s. 501.

${ }^{46}$ Stajonevic, agm, s. 456; Imber, Mehmed'in 1415 yazı başında ve ortasında Karaman Beyliği'ne saldırdığı ve Batı Anadolu'ya yöneldiğini varsaymaktadır. Bkz. Imber, age, s. 78.

${ }^{47}$ Uzunçarşıl1, agm, s. 501.

${ }^{48}$ Imber, age, s. 78.
}

\author{
History Studies \\ www.historystudies.net
}


operasyonlarına neden oldu. 1415 yılında Çalı Bey komutasında 13 adedi kadırga olmak üzere 112 gemiden oluşan bir Osmanlı filosu Ege'ye yelken açtı ve Andros, Paros ve Melos adalarını vurarak birçok esir aldı. Mehmed'in filosu, askerî operasyonlarını yağmaladığı Euboia adasına kadar genişletti. Ada açıklarında karşılaştığı bazı Venedik gemilerini ele geçirdikten sonra Gelibolu'ya döndü. ${ }^{49} \mathrm{O}$ sirada Mehmed, teslim olduğunu ilan eden Ege'nin diğer Latin hükümdarları arasında yer aldığı için Naksos'un Venedikli dükünü de cezalandırmak istedi. 1414 yılında İzmir'de Cüneyd'e karşı yürüttüğü sefer sırasında Naksos elçisini huzuruna kabul etti. Mehmed, Venedikli Bodonitsa markizinin Thermopylae bölgesine kadar uzanan topraklarını ilhak edince Venedik ve Atina Dükü Antonio Atzagioli Osmanlı karşıtı bir ittifak için harekete geçti. Arazisi Attika ve Boeotia'ya kadar uzanan Atzagioli, Osmanlı devleti ile sınırdaştı ve kendisini tehdit altında hissettiğinden bu ittifaka önem veriyordu. 8 Ocak'ta Venedik Senatosu, bu bilgileri Konstantinopolis'teki balyozuna iletti. O sırada I. Bayezid'in Ankara savaşında kaybolan oğlu Mustafa Çelebi olduğunu ilan eden ve Osmanlı tahtında hak iddia eden (Osmanlı kroniklerinin "Düzmece" sıfatını yakıștırdıkları) bir kiși,${ }^{50}$ Mehmed'e karșı yardım almak için Venedik ile temasa geçti. ${ }^{51} 8$ Ocak tarihli senato kaydına göre Venedik, Mustafa'ya o sırada Mehmed ile barış içinde olduğu için yardım edemeyeceği bildirdi. Görünüşe göre Venedikliler, ayrı bir anlaşma yapmayı umdukları Mehmed'i kışkırtmaktan korktukları için Mustafa'yı desteklemeyi reddettiler. Bununla birlikte, Mustafa'ya sempati göstermeyi de ihmal etmediler. Zira o sırada Mehmed, iki Venedikli elçiyi, Francesco Foscati ve ardından Dolfin Venier'i kabul etmişti. Ne var ki 1416 Mart ayı sonunda elçi atanan Venier, sultanla bir barış antlaşması yapmayı başaramad1. ${ }^{52}$

Mehmed, Foscati ve Dolfin Venier'in başarısız elçiliğinin ardındaki Venedik askerî gücünü küçümsemesinin bedelini ağır ödedi. 1416 yılında saldırgan bir politika benimseyen Venedik, Osmanlı donanmasının Euboia'daki faaliyetlerinin intikamını almak istedi. Amiral Pietro Loredano komutasındaki Venedik donanması, 29-30 Haziran'da Gelibolu açıklarında Çalı Bey'in filosuyla karşılaştı. Bu deniz savaşında Osmanlı donanması ağır bir yenilgiye uğradı ve Çalı Bey hayatını kaybetti. ${ }^{53}$ Diğer yandan Loredano da ağır şekilde yaralandı ve Tenedos'a (Bozcaada) çekilmek zorunda kaldı (29 Mayıs 1416). Ertesi yıl Lâpseki (Lampsakos) kıyılarında yeniden

${ }^{49}$ Dukas, s. 119; Thiriet, age, no. 1569, 1573, 1584, 1588, 1597, 1598.

50 Dukas, s. 155.27-28: “Mehmed'in) kardeşi, yukarıda bahsedilen Bayezid'in oğlu Mustafa olduğunu söyleyen Mustafas adlı birinden bir mesaj geldi...”; Neşrî, Mustafa'nın Mehmed'e karşı isyanından hiç bahsetmediği gibi bu olay1 II. Murad dönemine tarihlemektedir: "Şöyle rivayet ederler ki çün Sultan Murad Bursa'da tahta geçti. Yıldırım Han oğlu Mustafa ki Timur cenginde atından ayırtlaşıp gaip olmuştu. Selanik'te zahir oldu ki Düzme Mustafa demekle maruftur." Bkz. Neşrî, s. 556-557; Modern tarih yazımı Osmanlı kroniklerinin rivayetini takip izlemektedir. Ancak İnalckk, Mustafa'nın Ankara savaşında esir düştüğüne ve 1415'te Timur'un oğlu Şahruh tarafından serbest bırakıldığına dikkat çekmekte; Timur'un, bu yolla dikkatini dağıtarak Mehmed'i zararsız hale getirmeye çalıştığını düşünmektedir. Bkz. İnalcık, agm, s. 974 ve 976; Osmanlı kaynakları Mustafa'nın 1415-1419 yılları arasındaki faaliyetleri hakkında sessizliğe gömülmektedir.

${ }^{51}$ Miller, age, s. 36-437; Setton, age, s. 5.

52 Jorga, Notes et Extraits, s. 245-247; Thiriet, age, no. 1608-1609.

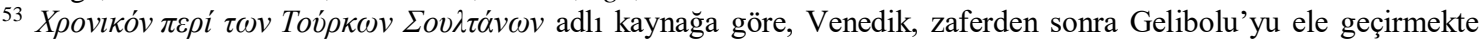
zorluk çekmeyecekti. Osmanlı donanma mürettebatının çoğu kaybolmuştu. Loredano, Gelibolu'yu ele geçirebilecek durumda olmasına rağmen gücünün sınırlarını zorlamadı. Amiralin Venedik'e gönderdiği raporlara göre, Osmanlılar 6 galera, 9 galiota ve 15 "fusta" kaybetmişti. Yitip giden mürettebat arasında sadece Türkler değil, ağır kayıplar veren Cenevizliler, Katalanlar, Sicilyalılar, Provençal vatandaşları, Giritliler ve Bizanslılar da vardı. II. Manuil, Gelibolu yakınlarında Venediklilere esir düşen Bizanslı tebaanın serbest bırakılmasını istemek zorunda kaldı (31 Mayıs 1418).

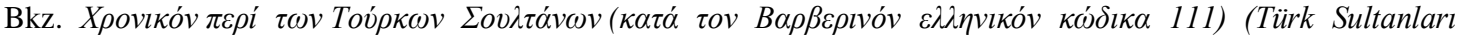

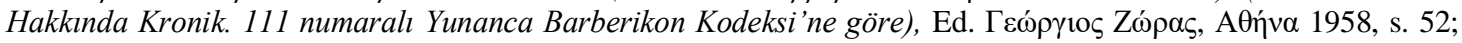
Jorga, Notes et extraits, s. 281-282; Thiriet, age, no. 1705; Djuric'e göre, Bizanslıların bu meselede oynadıkları önemsiz rol, Bizans yazarlarının bu savaşla ilgili sessizliğinin nedenlerinden biri olmalıdır. Bkz. Djuric, age, s. 173174; Ayrıca bkz. Donald Nicol, The Last Centuries of Byzantium, Hart-Davis, London 1972, s. 345; Uzunçarş111, agm, s. 501.

\author{
History Studies \\ www.historystudies.net
}


ortaya çıktı. Loredano, yaptığı baskına rağmen kenti ele geçiremedi. ${ }^{54}$ Venedik, 29-30 Haziran 1416 tarihindeki görkemli zaferiyle birkaç on yıl boyunca Doğu Akdeniz'in hâkimi oldu.

Gelibolu savaşı, Bizanslı elçilerin Constance Konsili'nde Avrupalıları Osmanlılara karşı Bizans'a yardıma ikna etmeye çalıştıkları sırada gerçekleşti. Elçiler, Avrupa'daki muhataplarını Bizanslıların Doğu ve Batı kiliseleri arasındaki ayrılığa (şizma) son verme kararlılıkları konusunda ikna etmek için diplomatik bir savaş vermekteydi. Konsile katılan Avrupalılar, Bizans'a yardım edeceklerine, ayrıca Heksamilion suru inşa masraflarına ve Venedik' in vermeyi reddettiği her konuda destek sözü verdiler. ${ }^{55}$ Papalık ve Avrupa ile diplomatik temaslara yoğunlaşan II. Manuil, Gelibolu'daki Osmanlı yenilgisinden sonra Venedik yardımıyla Bizans'ın durumunu iyileştirme fırsatını kaçırdı. Öte yandan, imparator ile VIII. İoannis, çoktandır dağılmış olan imparatorluk filosunu yenilemeye çalışmaktaydı. Bu tür çabaların Osmanlılar üzerinde bask1 oluşturup Bizans'1 yaklaşan tehditten kurtarabileceğini düşünmekteydiler. ${ }^{56}$ II. Manuil, Batı Avrupa'dan yardım beklerken, Osmanlı tarafında imparatorluk açısından oldukça elverişli gelişmeler olmaktaydı. Zira yukarıda bahsedildiği üzere o dönemde çaresizce ve ssrarla Batı Avrupa saraylarının desteğini arayan tek kişi Bizans imparatoru değildi.

\title{
3) Şehzade “Düzmece” Mustafa Meselesi
}

Osmanlı sultanına karşı askerî destek elde etmek umuduyla Batı Avrupa'da diplomatik temaslarda bulunanlar sadece Bizanslı elçiler değildi. I. Bayezid'in Timur tarafindan serbest bırakılan, 1413 yılında ortaya çıkarak I. Bayezid'in kayıp şehzadesi olduğunu ilan eden ve Osmanlı tahtı üzerinde hak iddia eden şehzade Mustafa da ${ }^{57}$ Batı Avrupa'da çaresizce ve israrla yardım arayışındaydı. ${ }^{58} \mathrm{Bu}$ sayede I. Mehmed'in topraklarını parçalamak ve devletini yıkıma

${ }^{54}$ Modern tarih yazımı, sonraki görüşmelerde Venedik-Osmanlı barış antlaşmasına II. Manuil’in aracılık ettiğini iddia eden Sphrantzes'in anlatısını takip etmektedir. Bkz. Jorga, Geschichte, s. 372; Uzunçarşılı, agm, s. 501; Halil İnalcık, "Mehmed I", İslam Ansiklopedisi, C. VII (1957), s. 502.

55 Sphrantzes, II. Manuil’in 1425 y1lındaki ölümünden önce oğlu VIII. İoannis arasında geçen bir diyaloğu aktarmaktadır. Bu diyalogda yaşlı imparator, Union fikrine karşı olduğunu belirtmektedir. Bkz. Sphrantzes, s. 1046C1047B. Bu anlatı, günümüz tarihçileri tarafından da takip edilmektedir. Bkz. Donald M. Nicol, Church and Society in the Last Centuries of Byzantium, Cambridge, Cambridge University Press, 1979, s. 109, 122; Djuric, Bizansl1 tarihçilerin II. Manuil'in Ortodoks Kilisesi'nin Katolik Kilisesi ile birleşmesine (Union) karşı olduğuna dair anlatılarının gerçeği yansıtmadığını ve sadece Kiliselerin Ayrılığı (Şizma) hakkındaki şahsî görüşlerini aktardıklarını düşünmektedir. Tarihçi, imparatorun sağlık sorunları onu istifa etmeye zorlayana kadar Union fikrini desteklediğini savunmaktadır. Bkz. Djuric, age, 214, not. 1, Sphrantzes, II. Manuil'in ölümünden (1425) önce VIII. İoannis arasında geçen bir diyaloğu aktarmaktadır. Bu diyalogda yaşlı imparator, Union fikrine karşı olduğunu belirtmektedir. Bkz. Sphrantzes, s. 1046C-1047B. Bu anlatı, günümüz tarihçileri tarafindan da takip edilmektedir. Bkz. Donald M. Nicol, Church and Society in the Last Centuries of Byzantium, Cambridge, Cambridge University Press, 1979, s. 109, 122;

${ }^{56}$ Diplomatarium Veneto-Levantinum sive Acta et Diplomata Res Venetas, Graecas atque Levantis Illustrantia, C. II, Ed. G. M. Thomas - R. Predeli, a. 1351-1454, Venetia, 1889, s. 261; Djuric, age, s. 165, not. 1.

${ }^{57}$ I. Mehmed'in taraftarlarının propagandasını yapan resmî Osmanlı vakanüvistleri, Mustafa'yı I. Bayezid'in gerçek oğlu olarak tanımamakta, onu bir sahtekâr olarak göstermek için Mustafa'nın Ankara savaşında öldürüldüğünü iddia etmektedir. Dukas ve Neşrî, bu görüşü paylaşmamaktadır. Dukas, s. 155.27-28: “Oradayken, adı geçen Bayezid'in oğlu Mustafa ve (Mehmed'in) kardeşi Vlahya'da bulunduğunu bildiren bir mesaj geldi."; Neşrî, Mustafa Çelebi'nin isyanı hakkında hiçbir şey söylemediği gibi ve olayı II. Murad zamanında olmuş gibi göstermektedir. Neşrî, s. 556557: "Şöyle rivayet ederler ki çün Sultan Murad Bursa'da tahta geçti. Yıldırım Han oğlu Mustafa ki Timur cenginde atından ayırtlaşıp gaip olmuştu. Selanik'te zahir oldu ki Düzme Mustafa demekle ma 'ruftur."; Günümüz tarihçileri Osmanlı kroniklerinin rivayetlerini doğru kabul etmektedir. Bkz. Ernst Werner, Die Geburt einer Grossmacht-die Osmanen (1300-1481): Ein Beintrag zur Genesis des türkischen Feudalismus, Bohlau, Berlin, 1966, 196; Ancak İnalcık, Mustafa'nın Ankara savaşında Moğolların eline esir düştüğüne, 1415 yılında Timur'un oğlu Şahruh tarafından serbest bırakıldığına dikkat çekmektedir. Tarihçi, Mustafa'yı serbest bırakan Moğol hükümdarının amacının Mehmed'in dikkatini dağıtarak ona zarar vermek olduğunu ileri sürmektedir. Bkz. İnalcık, "Mehemmed I", s. 974 ve 976.

${ }^{58}$ Mustafa, Ragusa Senatosunun Macar kralı Sigismund'a gönderdiği bir mektupta siyaset sahnesine çıkmaktadır (28 Kasım 1413). Mektup, Mehmed ile kardeşlerinden biri arasındaki anlaşmazlıktan bahsetmektedir. Bkz. Diplomatarium relationum Reipublicae Ragusanae cum regno Hungariae, Ed. Gelcich, Jozsef-Lajos Thalloczy, Magyar Tudományos Akadémia, Budapest 1887, no. 154, s. 234-235; Ayrıca bkz. Barker, age, s. 340-341.

\author{
History Studies \\ www.historystudies.net
}


sürükleyebilecek kadar avantajlı bir konumda oldukları için koşullar bir kez daha Manuil ile Venedik'in yüzüne gülmüştü. Mehmed'in filosu, Venediklilerle savaşırken (29 Haziran 1416), kara ordusunun büyük kısmı Bizans imparatoru ve Vlah voyvodası Mircea gibi Hiristiyan hükümdarların desteğiyle Rumeli'ye geçirilen Mustafa ile savaşmaya başlamıştı. Şehzade, önce Konstantinopolis'e bir elçi göndererek Bizans imparatoruyla temasa geçmek istedi. Ancak Manuil, henüz başkentine dönmemişti; o sırada hâlâ Mora'da idi. Mustafa'nın elçisi, bunun üzerine Ocak 1415'te Venedik'e gitti. Senato, 18 Ocak'ta şehzadeyi Doğu'dan Avrupa'ya getirecek bir kadırga talep eden elçiyi dinlemeyi kabul etti. Elçi, Venedikli senatörlere şehzadenin Rumeli'de çok sayıda destekçisi olduğunu söyledi. ${ }^{59}$ Senato, Konstantinopolis'teki balyozunu bilgilendirdi. Mustafa'nın elçisine Venedik'in şehzadeye dostluğu konusunda teminat verdikten sonra kendisine herhangi bir resmî destek veremeyeceğini, çünkü Mehmed ile dostça ilişkileri olduğunu bildirdi. ${ }^{60} \mathrm{O}$ sırada Venedik, Mehmed ile riske atmak istemediği bir anlaşma için müzakereler yapmaya çalışıyordu. Bunu riske atmamak için Mustafa'nın tüm iddialarını Mehmed'e bildirmeye karar verdi. ${ }^{61}$

Bu arada kaynaklar, şehzade Mustafa'nın 1415-1419 yılları arasındaki faaliyetleri hakkında sessiz kaldığından onun Venedik'e elçi gönderdikten sonra başkentine dönmüş olan Manuil ile görüşmek için bir girişimde bulunup bulunmadığını bilmiyoruz. Dölger, bir Venedik belgesindeki ipucuna dayanarak 1415 yazında II. Manuil'in Mehmed'e karşı Mustafa, Stefan Lazareviç ve Karamanoğlu ile bir anlaşmaya vardığını iddia etmektedir. ${ }^{62}$ Öte yandan siyasî atmosfer, gerçekten de böyle bir ittifak için çok elverişli görünmektedir; Karamanoğlu, Osmanlı ordusunun saldırısı altındaydı ve Mehmed'i barışa zorlamak için kesinlikle bir desteğe ihtiyacı vardı. Mustafa da Rumeli'ye geçebilmek ve Edirne'de tahta çıkmak için destek arıyordu. Mustafa ile Karamanoğlu'nun Osmanlı tehdidiyle nasıl ve ne zaman başa çıktığını öğrenmek için başka kaynaklarda hiçbir kanıtımız olmasa da her iki taraf da Manuil'in de desteğini alan bir ittifaka katılmakta zorlanmamış olmalıdır. Çünkü Mehmed'in uzaklaşmasını sağlamak amacıyla Mustafa'nın Rumeli'ye geçirilmesi için her ikisinin de Bizans gemilerine ihtiyacı olacaktı. Bu noktada Mehmed'in Süleyman'a karşı aynı nedenlerle bu Hıristiyan güçler ve Türk beyliklerinin ortak bir operasyonuyla Musa Çelebi'nin Rumeli'ye geçirilmesini sağladığını hatırlayalım. Osmanlı operasyonlarıyla karşı karşıya kalan Karamanoğlu, geçmişte Musa'nın yanında olduğu gibi şimdi de memnuniyetle Mustafa'nın da yanında yer almış olmalıdır. Nitekim Ragusa Senatosu'nun 18 Ağustos 1415 tarihinde Macar kralı Sigismund ile ilgili raporu, Mustafa'nın Karadeniz'den Vlah ülkesine geçtiğini ve voyvoda Mircea'nın askerî desteğini sağladığını

\footnotetext{
${ }^{59}$ Senato, Venedikli bir tüccardan gemisine bir Türk'ü kabul ettiğini, adamın Mustafa'nın elçisi olduğunu ve görevinin efendisi adına imparatorla pazarlık yapmak olduğunu söylediğine dair bir rapor aldı. Buna göre; elçi, imparatorun başkentinde olmadığını öğrendiğinde yönünü Ocak 1415'te ulaştığı Venedik'e çevirdi. Bkz. Jorga, Notes et Extraits, s. 225; Thiriet, age, no. 1563; Barker, age, s. 340, not. 80.

${ }^{60}$ Mehmed, önce Francesco Foscati sonra Dolfin Venier'i huzuruna kabul etti. Bkz. Thiriet, age, no. 1608-1609; Jorga, Notes et Extraits, s. 245-247.

${ }^{61}$ Jorga, Notes et Extraits, s. 226; Thiriet, age, no. 1564.

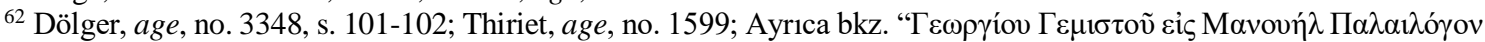

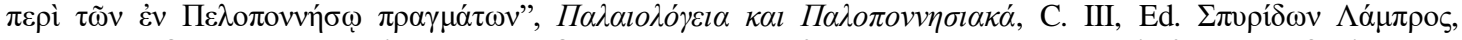

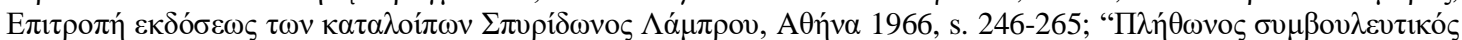

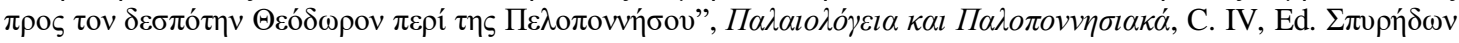

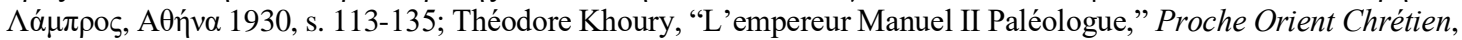
C. XV (1965), s. 143; Barker, Manuil'in barışı riske edecek şekilde Sultan ile barış yapmak gibi bu kadar hızlı bir adım atmayacağına inanmaktadır. Ayrıca 1415 baharında Mustafa'nın hala Trabzon'da olduğunu ve Stefan Lazarevic ile iletişime geçip ittifak kurmasının zor olacağını belirtmektedir. Bkz. Barker, age, 340, not. 80 ve 81 . Ne var ki bu tam olarak doğru olamaz; çünkü şehzadenin Stefan ile doğrudan iletişime geçmesi çok elzem değildi. Zira şehzadeyi Anadolu'da Balkanlardaki Osmanlı karşıtı Hristiyan müttefikleriyle iletişime geçirecek güç odaklarının olduğu aşikârdır. Bu çok taraflı müttefik grubunun Mustafa ortaya çıktığında yeniden devreye girdiğini düşünmek yanlış olmayacaktır.
}

\author{
History Studies \\ www.historystudies.net
}


kanıtlamaktadır. ${ }^{63}$ Görünüșe göre Mehmed'i tahttan devirmek isteyenler sadece Mustafa ve Mircea değildi. Ayrıca İzmir emîri Cüneyd ${ }^{64}$ de kısa sürede onlara katıldı. Mustafa'nın Vlah ülkesine geldiğini öğrenen Cüneyd şehzadeyi bulmak ve destek vermek üzere harekete geçti. Mustafa, 1416 yılının ikinci yarısında Tuna nehrini geçerek "Bulgaristan'a girdi." Ragusa Senatosu'nun bir raporuna göre (12 Ekim 1416), sultanın Karamanoğlu ile savaşından yararlanan isyancı birlikler, Mehmed'in Mustafa'nın saflarına geçen önemli sayıda askeriyle Balkan yarımadasının iç kısımlarını tahrip etti. ${ }^{65}$ Böylece Mustafa'nın ortaya çıkışı, Osmanlı Devleti'nin yeniden güçlenmesine karşı tedbirler alan güney Yunanistan ve Ege'deki Hıristiyan güçlerinin kararlılığını arttırdı. Sultan Mehmed'in Mustafa'ya karşı harekete geçmesi uzun sürmedi. Dukas'a göre, Mehmed, Mustafa'nın Vlah ülkesinde olduğunu öğrenince şehzadenin koruyucusu olan Cüneyd'in kafasını kesmeleri için iki adamını gönderdi. Ama Cüneyd, çoktan Tuna'yı geçmiş, Mustafa'ya itaatini sunmuş ve şehzadeyi devletin doğu ve batı yarısınını hâkimi olarak tanımıştı. Bunun üzerine Mehmed, büyük bir orduyla Trakya'dan Makedonya'ya yürüdü. ${ }^{66}$ Rakibinin Vlahlar ve kalabalık Türk askerlerinin yardımıyla Tuna'yı geçerek "Tesalya'ya (kastedilen Thessaloniki kentidir)" indiğini öğrendi. Bu yolu izleyen Mehmed, düşmanıyla 1416 'da "Thessaloniki'nin dış mahallelerinde" karşılaştı. Mustafa, savaşta yenildi. ${ }^{67}$ Vlahlar dağıldı. Mehmed, Mustafa'yı Thessaloniki kapılarına kadar takip etti. ${ }^{68}$ Dukas'a göre, kent ahalisinden çok az kişi savaşta Mustafa ile Cüneyd'e yardım etti. Nihayet iki âsî "istenmedikleri" Thessaloniki'ye girdiklerinde onları despot Dimitrios Laskaris Leontaris karşıladı. Kent, Türklere teslim olsa bile onları Mehmed'e teslim etmeyeceğine dair güvence verdi. ${ }^{69}$ Dukas'a göre, sultan, sabahın erken saatlerinde kent surlarının önüne geldi. Âsîleri derhal teslim etmesi için Dimitrios'a şu mesajı gönderdi: "Romalıların imparatoruna olan sevgimi ve onunla yakın dostluğumu iyi

${ }^{63}$ Ragusa Senatosu'nun Macar Kralı Sigismund'a gönderdiği raporlar sayesinde Mustafa'nın hareketlerini takip edebilmekteyiz. 28 Haziran 1415 tarihli ilk rapor, Karaman beyinin Bursa'ya saldırarak Mehmed ("Chirisius")'i taciz ettiğinden bahsetmektedir. Görünüşe göre "Muscat" (Mustafa), 1415 yılı baharına kadar hala Trabzon civarındaydı. Ancak aynı yılın 18 Ağustos ayına ait ikinci bir raporda, şehzadenin adını doğru ifade eden Ragusa senatosu şöyle yazmaktadır: "do barones imperatoris Turcorum aufugerunt ab eo ad fratrem suum Mustafa, qui moratur in Vlachia...” Bkz. Diplomatarium relationum Reipublicae Ragusanae, no. 167, s. 249 ve no. 168, s. 251. Bu iki rapordan, Mustafa'nın 1415 yazının başlarında artık Avrupa'ya geçmiș olması gerektiği anlaşılmaktadır.

${ }^{64}$ Cüneyd, Osmanlı-Vlah ülkeleri sınırdaki Niğbolu'nun valisiydi. Cüneyd'in faaliyetleri için bkz. Johannes Heinrich Mortmann, "Djunaid," Encyclopedia of Islam, C. 1 (1986), s. 1063-1064; Colin Heywood, "Mustafa Çelebi. Düzmece" Encyclopedia of Islam, $2^{\text {nd }}$ ed., C. VII (1992), s. 710-712; Dukas, onun adını Cineyt ya da Cineitis olarak, Halkokondyles ise Zunaitis olarak telaffuz etmektedir. Bkz. Gyula Moravcsik, Byzantinoturcica. Sprachreste der Türkvölker in den byzantinischen Quellen, C. II, Kir. M. Pázmány Péter tudományegyetemi görög filológiai intézet, Budapest 1943, s. 313; Akdes Nimet Kurat, Die türkische Prosopographie bei Laonikos Chalkokandyles, Neimann \& Moschinski, Hamburg 1933, 45-46, 82; Joseph Hammer-Purgstall, Geschichte des osmanischen Reiches, C. I, C. A. Hartleben, Pest 1833, s. 364-366; Jorga, Geschichte, s. 369-370.

${ }^{65}$ Venedik belgeleri Mustafa'nın ilk Rumeli operasyonundan söz etmektedir. Bkz. Diplomatarium Veneto-Levantinum, no. 173, s. 261: "[Karaman beyliğine yönelik askeri operasyonlarla hala meşgul olan] Mehmed ya da "Crixia”, ... O Mustafa, frater dicti rixie, videns ipsum Crixiam defulcitum gentibus, venit cum aliquibus Teucris secum colligates et aliquibus Vlachis voivode Mirce usque in regnum Bulgarie, quod regnum continue vastat et dextruit. Stephanus autme despoth Sclavonie stat in quiete, quia dictus Crixia Theucer undique est occupatus.” Bkz. Stanojevic, agm, s. 456-457; Jorga, Geschichte, s. 369-370; Imber, age, s. 81; Djuric, age, s. 165, not. 2 ve s. 176.

${ }^{66}$ Dukas, s. 155.27.-157.4.

${ }^{67}$ Mustafa'nın bu ilk isyanının tarihi konusu tartışmalıdır. Bazı tarihçiler, olayı 1418 ya da 1419 yılının sonuna tarihlemektedir. Sphrantzes'in ifadesi, isyanın 1416 yılında olduğunu göstermektedir. Ragusalıların kral Sigismund'a gönderdikleri bir belgeye (25 Aral1k 1416) göre, “Türklerle ilgili gelen haberlere gelince: Bosna'da ve Rascia'da şu anda ordu yok, çünkü onların imparatoru [Mehmed], Konstantinopolis'in imparatorunun iltifatta bulunduğu, önce Vlah ülkesinde şimdi ise Thessaloniki 'de bulunan kardeşini kuşatmakla meşguldür.” Bkz. Diplomatarium relationum Reipublicae Ragusanae, no. 175, s. 264-266, s. 265 ve s. 263: Filozof Konstantin, çok kısa da olsa konu hakkında bilgi vermektedir. Bkz. Lebenschreibung des Despoten Stefan Lazarević von Kostantin dem Philosophen, Ed. Maximilien Braun, Göttingen, 1956, s. 57; Stanojevic, agm, s. 456 ve 458.

${ }^{68}$ Dukas, s. 157.4-9; Djuric, age, s. 179, not. 1.

${ }^{69}$ Dukas, 157.9-25. Klaus Peter Matschke, Die Schlacht bei Ankara und das Schicksal von Byzanz. Studien zur spätbyzantinischen Geschichte zwischen 1402 und 1422, Böhlau, Weimar 1981, s. 1981, 103.

\author{
History Studies \\ www.historystudies.net
}


biliyorsun. Bu nedenle bunu parçalayıp yok etmek istemeyin, (bu) Romalıların soyu için büyük bir yıkıma neden olur ve Türkler ile Romalılar arasında şiddetli bir düşmanlık yaratır. O yüzden kovaladığım avi hemen bana geri ver. Bunu yapmazsan dostluğa veda edeceğim ve nefrete sarılacă̆ım ki kisa sürede kentinizi işgal edeceğim ve sakinlerini esir edeceğim ve canını alacağım ve sonunda düşmanlarımı ellerimle yakalayacağım."

Sphrantzes'e göre, o sirada Bizans prensi (VIII.) İoannis Palaiologos da kentte idi ${ }^{71}$ ve Mehmed ile müzakerelerde önemli rol oynadı. Dukas'a göre Mehmed, bu sözleri duyunca mesajın gönderilmesine izin verdi. Leontaris, Mehmed'e imparatorun onayı olmadan kaçakları teslim edemeyeceğini belirten bir mektup gönderip sabırlı olmasını istedi. İmparatora olayı açıklayan bir mesaj gönderdiğini ve ondan talimat beklediğini de bildirdi. ${ }^{72} \mathrm{Bu}$ arada imparatora olayları anlatan bir mektup yazdı. II. Manuil, Mehmed'e şu cevabı verdi: "Bildiğin gibi, ben senin baban olacağıma ve sen de benim oğlum olacağına dair söz verdik. Yani ikimiz de sözlerimizi tutarsak, o zaman, evet, Tanrı'dan korkarı ve O'nun emirlerini yerine getiririz ama ĕger onları çiğnersek ne yazık ki, baba oğluna ihanet etmiş görünecek ve oğul babasının katili olarak adlandırılacaktır. Ben yeminlerimizi tutacağım, ama sen sadık kalmak istemiyorsun. Öyleyse, her kim haksızlı̆̆a uğruyorsa onun intikamını alan Tanrı, aramızdaki âdil yargıç olsun. Bu mültecilerin senin ellerine teslimini duymak bile istemiyorum. Böyle bir şey bir imparatora değil, bir tirana yakışır. Kardeşimi kovalasaydım ve kaçtığında kanatların altına sığınsaydı ve ben onu senden isteseydim, onu öldüreceğim için şüphesiz onu sen de bana teslim etmezdin. Onu bana teslim etmişs olsaydın bile, insanlık dlşı bir şey yapardın ve hain ve katil olurdun. Benim yüzümden böyle bir şeyin asla olmayacağını bil. Ama baban olmaya söz verdiğim için, tek Tanrı ve biz Hıristiyanların ibadet ettiği Kutsal Teslis üzerine yemin ederim ki ne mülteci Mustafa ne de arkadaşı Cüneyd, senin hayatının sonuna kadar ve saltanatının sonuna kadar hapisten çıkmayacak. Senin ölümünden sonrasına gelince, birakalım işler yolunda gitsin. Kabul etmiyorsan, düşündügün gibi yap.,"ㄱ II. Manuil, ayrıca Dimitrios Leontaris'e şu emri gönderdi: "Yazdlklarımızı oku ve olabildiğince çabuk yerine getir. Derhal kaçakları, yani Mustafa, Cüneyd ve taraftarlarını bir gemiye koy ve en hızlı şekilde bize gönder, emrimiz olmadan başka bir şey yapma." ${ }^{.74}$

\footnotetext{
${ }^{70}$ Dukas'a göre Mehmed ile Mustafa Çelebi meselesini müzakere eden kişi Dimitrios Laskaris Leontarios idi. Bkz. Dukas, s. 157.17-25; Aynı rivayeti daha az ayrıntıyla aktaran Halkokondyles'e göre kaçakların sığınma talebinden

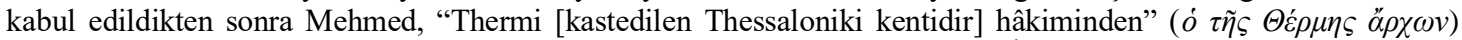
bunların iadesini istedi. Bu yetkili, konuyu "Bizans imparatoruna" bildirdi. İmparator da sultan ile kaçakların hapsedilmesini kararlaştırdığı bir anlaşma imzaladı. Bkz. Halkokondyles, s. 190-192. Thermi, Thessaloniki yakınlarında bir yerleşim yeridir. Bkz. Barker, age, s. 342-343, not. 83.

${ }_{71} \mathrm{Bu}$ sırada Thessaloniki'de bulunan VIII. İoannis, I. Mehmed ile Mustafa ve Cüneyd'in kaderi hakkındaki müzakerelerde kilit rol oynadi. Bkz. Sphrantzes, s. 1026D-1027A. VIII. İoannis'in Mustafa meselesi sirasında kentte bulunduğu Panigirikos adlı anonim bir eser tarafından da doğrulanmaktadır. İoannis'in "Basileus (imparator)" sıfatıyla ön plana çıkarıldığı bu eser, ne Leontaris ne de II. Manuil'in konuya dahlinden bahsetmemektedir. Bkz.

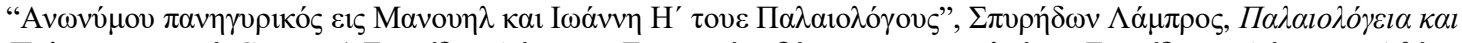

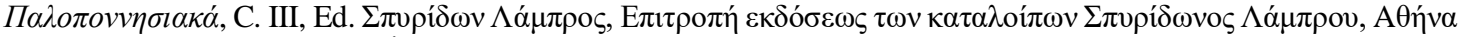

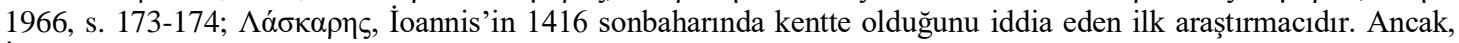

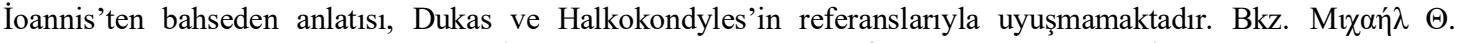

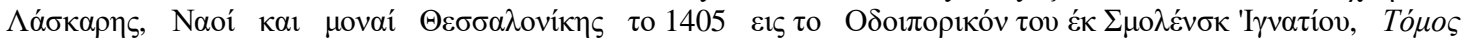

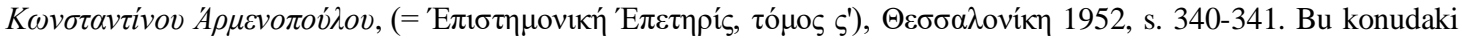
tartışmalar için bkz. Jorga, Geschichte, s. 374; Barker, age, s. 342-343; Djuric, age, s. 176, not. 5 ve 2; Balfour, age, s. 50; Ferhan Kırlıdökme-Mollaoğlu, Selanik Basspiskoposu Symeon'un Tarihi Nutku (1387-1429) The historical discourse of the archibishop of thessaloniki (Selanik) Symeon (1387-1429), (Ankara Üniversitesi Sosyal Bilimler Enstitüsü Yayımlanmamış Yüksek Lisans Tezi), Ankara 1998, s. 50, 54-58.

${ }^{72}$ Dukas, s. 157.25-35; Djuric, age, s. 176; Balfour, age, s. 131; Djuric, age, s. 176, not. 5; Dölger, age, no. 3361 ve 3365.

${ }^{73}$ Dukas, s. 157.36-159.16.

${ }^{74}$ Dukas, s. 159.16-20.
}

\author{
History Studies \\ www.historystudies.net
}


$\mathrm{Bu}$ arada imparatorla çatışırsa ne olacağını hesaplayan Mehmed, hayatta olduğu sürece Mustafa ve Cüneyd'in hapisten çıkarılmayacağı güvencesini alınca kuşatmayı kaldırdı. Âsîler yüzünden düşüncelerine hâkim olan endişe ve kaygılardan sıyrılıp ordusuyla Edirne'ye gitti. ${ }^{75}$

Dukas, Bizanslıların bu sırada bir gemi hazırladığını ve iki kaçağı gemiye bindirdikten sonra Manuil'e gönderdiklerini yazmaktadır. İmparator, kısa süre sonra Mustafa'yı Limnos adasına gönderdi ve muhafizlarına onu çok dikkatli korumalarını emretti. Cüneyd ise Konstantinopolis'teki Pammakaristos manastırına kapatıldı. ${ }^{76}$

İmparator, daha sonra Mehmed'e haberciler göndererek Mustafa ile yanındaki otuz adamının ve Cüneyd ile on adamının masraflarını karşılamasını istedi. İmparator, Mehmed hayatta olduğu sürece Mustafa'nın serbest bırakılmaması karşılığında, Osmanlı hazinesinden yılda üç yüz bin altın alması konusunda sultanla anlaştı. Anlaşma gereği Mehmed'in ölümünden sonra imparator, kendi çıkarlarına ve Mehmed'in haleflerinin kendisiyle olan ilişkilerine göre hareket etmekte özgür olacaktı. Böylece Manuil, 1416'daki şartları Bizans'ın lehinde yönetmiş oluyordu. Mehmed'i Bizans ile barışı sürdürmeye zorlamak için Mustafa ve Cüneyd'i silah olarak kullanma firsatını da elde etmiş oluyordu. Ayrıca II. Manuil, mahkûmların giderleri için sultanı Bizans'a yıllık üç yüz bin altın ödemek zorunda bırakıyordu. ${ }^{77}$ Sultan Mehmed'in Bizans imparatorunun şartlarını kabul etmekten başka seçeneği yoktu. Çünkü bu kez sadece devletinin parçalanmasına neden olabilecek güçlü bir silahı elinde tutan dış düşmanlarla değil, kendi uyruklarının isyanına neden olabilecek dâhili tehdit unsurlarıyla da karşı karşıyaydı.

\title{
4) I. Mehmed ile II. Manuil Palaiologos'un Son Görüşmesi (1421)
}

İmparator Manuil'in oğlu (VIII.) İoannis, 1421 yılında Sophia Monferrat ile evlendi ${ }^{78}$ ve Ayasofya kilisesinde ortak-imparator olarak taç giydi. ${ }^{79}$ İoannis'in iktidara ortak olmas1, Osmanlı-Bizans ilişkileri tarihinde bir dönüm noktasıdır. Genç imparatorun fevrî karakteri, yakın gelecekte yaşanacak gelişmelerde kendini iyice hissettirecektir. Bu gelişme, Bizans başkentinde iki hizibin ortaya çıkmasıyla aynı zamana denk gelmektedir. Hiziplerden biri Manuil'in dış politikasını takip etmekte ve Osmanlılarla barışı savunmaktaydı. Üyeleri, barış ve Osmanlı vassallığının devamı görüşünü desteklemekte tereddüt etmemekteydi. Yirmi yedi yaşındaki İoannis'in temsilcisi olduğu savaş taraftarı diğer hizip, bu politikanın tamamen karşısındaydı ve Osmanlılara karşı daha dinamik ve enerjik bir tavırdan yanaydı. Bu hizip, daha sonra Bizans'ın kurtuluşunu sağlamak için Katolik Kilisesi ile Ortodoks Kilisesinin Birliği (Union) politikasını

\footnotetext{
75 Dukas, s. 159.20-25.

${ }^{76}$ Dukas, s. 159.25-29; Sphrantzes, s. 1026D-1027A; Halkokondyles, s. 190-192; Barker, age, s. 342-343, not. 83 ve 357-358.

${ }^{77}$ Dukas, s. 159.29-161.3; Barker, daha eski tarih yazımının anlaşmayı yanlışlıkla 1421 yılına tarihlediğine işaret etmektedir. Bkz. Barker, age, s. 342-344, not. 83; Halil İnalc1k, "Critica", s. 251-304.

78 Dukas, 137-139; Halkokondyles, s. 192-193; Georgios Sphrantzes, 1027C-D; Joseph Gill, "John VIII Palaeologus. A character study," Studi bizantini e neoellenici, 9 (1957), 155; Raymond J. Loenertz, "Autour du Chronicon majus attribué á Georges Sphrantzès", Miscelana G. Mercati, C. III, Rome 1946, s. 304-305; Charles Diehl, Figures byzantines, C. II, Colin, Paris 1908, s. 273-275; Zakythenos, age, s. 188-191; Barker, age, s. 349, not. 96.

79 Sphrantzes, İoannis'in ortak-imparator ilan edilişini yanlışlıkla 1419 yılına tarihlemektedir. Bkz. Sphrantzes, s. 1027D; Anonim Grekçe Kısa Kronik no. 9, bu olayla ilgili olarak yanlışlıkla 6900 (1391-92) yılını, Anonim Grekçe Kısa Kronik no. 22, ise doğru bir kronolojiyle 6929 dünya yılı (1420-21) yılını vermektedir. Bkz. Anonim Grekçe Kısa Kronik no. 9, paragraf 48, s. 98; Anonim Grekçe Kısa Kronik no. 22, paragraf 31, s. 185. Jules Berger de Xivrey, Sphrantzes'in kronolojisini takip etmektedir. Bkz. Jules Berger de Xivrey, Mémoire sur la vie et les ouvrages de l'Empereur Manuel Paléologue, Paris, 1851, s. 167. Dölger, kronoloji hatalarını düzeltti. Ayrıca Anonim Grekçe Kısa Kroniklerin verdikleri tarihlerin de yanlış olduğunu gösterdi. Bkz. Franz Dölger, "Die Krönung Johannes VIII. zum Mitkaiser," Byzantinische Zeitschrift, C. 36 (1936), s. 318-319. Dukas, İoannis'in ilk eşi Anna'nın genç yaş1 dolayısıyla taçtan mahrum bırakıldığını yazmaktadır. Bkz. Dukas, s. 133-135; Bu konudaki tartışmalar için bkz.

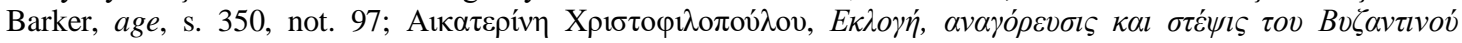

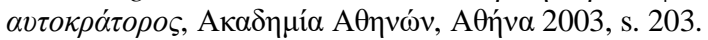

\author{
History Studies \\ www.historystudies.net
}


savunurken, Osmanlılarla barış yanlısı hizip, bu politikanın karşısında yer aldı. ${ }^{80}$ Savaş taraftarı hizibin tutumu, İoannis'in taç giyme töreninden hemen sonra Mehmed'in Manuil ile 1421 yılındaki son teması esnasında kendini hissettirdi. Osmanlı sultan1, o yıl Konstantinopolis üzerinden Anadolu'ya geçecekti. Sphrantzes'in bu konudaki anlatısı oldukça aydınlatıcıdır ve önemli ayrıntılar içermektedir. Bizanslı tarihçi, VIII. İoannis'in siyasi duruşunun babasınınkinden tamamen farklı olduğunu, onun Osmanlılarla savaştan yana olduğunu doğrulamaktadır. Sphrantzes, 1421 yılındaki temas hakkında şöyle yazıyor: "Archont (Efendi) Kyritzes (Mehmed), düzeni sağlamak için Edirne'den Anadolu'ya Konstantinopolis üzerinden geçmek istedi. Bu yüzden sultanın Konstantinopolis'e saldırmayı planladı̆̆ söylentileri kısa sürede yayıldı. Bizanslı soylular ve yüksek rahipler, yani savaş yanlısı hizibin üyeleri, bu firsatı değerlendirmesi için Manuil'e baskı yapmaya çalıştılar. Hazır Anadolu'ya geçerken Bizans gemilerini kullanacakken planını uygulamadan önce sultanı tutuklamasını istediler. Imparator, savaşı kışkırtacak bu önerileri reddederek, Mehmed'e verdiği (barış) sözünü tutmakta ısrar etti ve 'Beni bunun için suçlayacağınızı bilsem de yeminimi bozmayacağım. Sözünü çiğnerse, bırakın ondan daha güçlü olan Tanrı karar versin' dedi." Gelişmeler, savaş yanlısı hizibin iddia ettiği üzere Mehmed'in saldırgan bir eylemde bulunmaması nedeniyle imparatorun haklılığını gösterdi. Sphrantzes'e göre Manuil'in ne kendisi Mehmed'i karşılamaya gitti ne de bunun için oğlunu gönderdi. Dimitrios Leontaris, İsaakios Leontaris ve başkomutan Manuil Kantakuzinos gibi bazı Bizanslı soyluları bir askerî eskortla göndermeyi tercih etti. Ayrıca değerli hediyelerle aristokrat çocuklarını sultana gönderdi. Sphrantzes'in verdiği bir diğer ayrıntı ise, Mehmed'in Konstantinopolis'e girmediği, Bizanslıların onu Galata'ya iki kilometre uzaklıktaki banliyölerden Kutulos'ta (Kurtuluş) karşıladıklarına dairdir. Manuil ve oğulları, Mehmed'i Diplokionion'da (Beşiktaş) bir gemide bekliyorlardı. Orada sultana Leontaris'in eşliğinde Anadolu kıyısına geçmesi için bir gemi verildi. Bizans ve Osmanlı tarafi farklı gemilere bindi ve birlikte Chrysoupolis'e (Üsküdar) gittiler. Mehmed, orada gemiden indi ve Bizanslilar tarafindan kendisi için özel olarak hazırlanan çadıra yöneldi. İmparator gemisinde kalırken, taraflar birbirlerine yiyecekler göndererek ayrı çadırlarda öğle yemeklerini yedi. Öğleden sonra Mehmed, Nikomedia'ya (İzmit) doğru yola çıkarken, imparator da başkentine döndü. Bu, iki hükümdarın bir araya geldiği son buluşmaydı. İlkbaharda Mehmed, Gelibolu üzerinden Edirne'ye döndü. ${ }^{81}$ Manuil'in kararlı tutumu, Osmanlılarla ilişkilerin bozulmasını ve Bizans çıkarlarına karşı oluşabilecek ciddi sonuçları önledi. Çünkü Manuil, yüzeysel de olsa Mehmed ile barışın devamının bir gereklilik olduğunu biliyordu. Savaş yanlısı hizibin önerisini benimsemek, Bizanslılar için bir felaket olurdu ve yüzeysel de olsa dostluğu sürdürmenin en iyi alternatifi olamazdı. Bu olayla birlikte Manuil’in sağduyulu bir Osmanlı politikası izlediği anlaşılmış oldu. Mehmed'in 1421 yılındaki ölümünden kısa süre sonra patlak veren siyasi kriz, barışın hem Bizans hem de Osmanlı tarafi için de ne kadar elzem olduğunu gözler önüne serecekti.

\footnotetext{
${ }^{80}$ Dukas, Konstantinopolis'teki barış yanlısı grubun düşünce yapısını şöyle ifade etmektedir: “Şehirde Latin külahı görmektense Türklerin sultanlarının sarı̆̆ını görmek yeğdir.” Bkz. Dukas, s. 329.18-20; Walter'a göre Bizans başkentindeki savaş yanlısı hizip, barış ortamında büyüyen ve savaşın acı gerçeklerini görmeyen yeni neslin üyeleriydi. Bkz. Gérard Walter, La ruine de Byzance, 1204-1453, Paris 1958, s. 308; Barker, age, s. 351.

${ }^{81}$ Sphrantzes, 1420 yılına yerleştirdiği olaylara muhtemelen şahit olmuş ya da imparatorun maiyetinden bir kişi olarak olayları görgü tanıklarının ifadelerini dinleyip kaydetmiş olmalıdır. Bkz. Sphrantzes, s. 1027S-1028C. İmparator II. Manuil'in hayatı ve faaliyetleri üzerine eser yazan Berger de Xivrey de bu tarihi kabul etmektedir. Bkz. Berger de Xivrey, age, s. 169-171; Jorga, Geschichte, s. 376-377; Pears, age, s. 152; Hammer, Mustafa ile ilgili anlaşmayı ayn1 yıla yerleştirmektedir. Bkz. Hammer, age, s. 384-385. Bu olay1 1420-21 kışına tarihleyen Dölger, haklı olarak Hammer'in 1422 yılına kadarki kronolojisinin tamamen yanlış olduğuna dikkat çekmektedir. Bkz. Dölger, age, no. 3384. Khoury, Sphrantzes'in anlatısına dayanarak olayı 1420 yılı kışı sonuna yerleştirmektedir. Bkz. Khoury, agm, 143. Sphrantzes'in hikâyesine şöyle bir ifadeyle devam etmektedir: "Aynı yılın yazında Gelibolu yoluyla Batıya geri dönerek Edirne'ye geldi.” Bu konudaki tartışmalar için bkz. Berger de Xivrey, age, s. 171; Jorga, Geschichte, s. 376. Dölger, age, no. 3383; Jorga, Notes et Extraits, s. 301; Bkz. Barker, age, 354.
}

\author{
History Studies \\ www.historystudies.net
}




\title{
5) I. Mehmed'in Ölümü ve Bizans Vesayeti Meselesi
}

Sphrantzes'in anlatısına göre iki hükümdar 1421 baharındaki görüşmeden sonra diplomatik bir temasta da bulundu. Aynı yıl Manuil, güvendiği adamı Dimitrios Laskaris Leontaris'i elçi olarak Edirne sarayına gönderdi. Bizanslı tarihçinin bu elçilik konusunda özel ayrıntılar vermemesine rağmen, üslubundan o dönemde taraflar aralarında yoğun bir diplomatik faaliyet olduğu anlaşılmaktadır. ${ }^{82}$ Sphrantzes'in pek fazla bilgi vermediği bu noktada, bir diğer Bizanslı tarihçi Dukas'ın verdiği bilgiler, Bizanslı elçinin görevinin Mehmed'in vasiyetinin düzenlenmesi ve uygulanması ile ilgili olduğuna dair fikir yürütmemizi sağlıyor. Dukas, Mehmed'in Edirne'ye döner dönmez bir av kazası geçirdiğini ve iyileşemeyeceğini anlayınca vezir-i âzâmı Bayezid Paşa'yı çă̆ırdığını ve idareyi ona emanet ettiğini, bu arada vasiyetini yazdığını ve Bayezid Paşa'yı oğlu Murat'a sadık kalacağına dair yeminle bağladığını aktarıyor. Ayrıca Paşa'yı vasiyeti gereği iki küçük şehzadesini, sekiz yaşındaki Yusuf'u ve yedi yaşındaki Mahmud'u, İmparator Manuil'in vesayetine teslim etmekle görevlendirdi. İmparator, karşılığında Bizans gözetimindeki Mustafa'yı salıvermeyecekti. İki küçük şehzadenin bakımı için yıllık bir meblağ alacaktı. Mehmed, on yedi yaşındaki büyük oğlu Murad'ın tahta çıkışını garantilemek istiyordu. Bu nedenle imparator ile bir anlaşma yaptı. Buna göre, Murad, en büyük oğul olarak pratikte tek uygun halefi idi ve Edirne'de babasının yerini alacaktı. ${ }^{83}$ Ancak teoride, böyle durumlarda kimin önceliği olduğu hiçbir yasayla tanımlanmadığından küçük şehzadelerin dışlandığı göz ardı edilemezdi. Ayrıca hanedan üyelerinin halefleri olarak varlıkları, her durumda Murad'ı tahttan indirmeye yönelik olası bir girişime yol açabilecekti. Dahası, Mehmed'in devletinin Rumeli arazisini Murad'a ve Anadolu'yu dört oğlundan ("Küçük" lakabıyla tanınan) on iki yaşındaki Mustafa'ya bırakarak ortaya çıkabilecek hiziplerin önüne geçmeyi amaçladığına dair söylentiler vard1. ${ }^{84}$ Mehmed, üç gün içinde, ${ }^{85} 21$ Mayıs 1421 tarihinde öldü. ${ }^{86}$ Mehmed'in ölümü özellikle

82 Sphrantzes, Dimitrios’un elçiliğinden bahseden tek Bizanslı tarihçidir. Bkz. Sphrantzes, s. 1028C; Dukas, konuya değinmeden sultanın birine Rumeli'yi diğerine Anadolu'yu vererek devletini iki oğlu arasında paylaştırmak istediğini, bir çatışmayı önlemek için de iki genç şehzadesini imparatorun vesayetine göndermek istediğini yazmaktadır. Bkz. Dukas, s. 167. Hammer, age, s. 385-386; Jorga, Geschichte, s. 377, 378; Dölger, age, no. 3385. Barker, Mehmed'in Osmanlı devletini yeniden birleştirdikten sonra böyle bir söylenti karşısında devletini çelişkili bir bölünmeye götürecek bir düzenlemeyi planlamış olmasının oldukça garip göründügünü düşünmektedir. Bkz. Barker, age, 351-353 ve 354-355, not. 100.

${ }^{83}$ Dukas, s. 163.10-12: "Bir keresinde Mehmed, atıyla ormanda ava çıkt, o sırada ormandan önüne bir yaban domuzu çıktı̆̆ını gördüğünde, canavara karşı mızră̆ını firlatmak için davranınca epilepsi nöbeti sebebiyle atından yarı-ölü vaziyette düstü." Dukas, s. 65.11-15 ve 167.6-29; Sphrantzes, sadece Dimitrios Leontaris'in Edirne'de çok iyi karşılandığını belirtmekte, Mehmed'in vasiyeti hakkında bir bilgi vermemektedir. Bizanslı tarihçi onun görevini tamamlayamadığını çünkü "sultanın onu en büyük șeref ve dostluk ile karşıladığını, ancak üç gün sonra öldüğünü” aktarmaktadır. Bkz. Sphrantzes, s. 1028C. Bizans kaynaklarının bilgilerini doğrulayan Neşrî, Mehmed'in ciddi bir hastalıktan muzdarip olduğunu; iyileşemeyeceğini anlayınca vezirleri Bayezid ve İbrahim ve Hacı İvaz’’ çağırdığını, gizli bir görüşmenin ardından en büyük oğlu Murad'ın gizlice tahta çıkarılmasını emrettiğini kaydetmektedir. Bkz. Neşrî, s. 550-551.

${ }^{84}$ Halil İnalcık, "Murad II", İslam Ansiklopedisi, C. VIII (1997), s. 598-589; Colin J. Heywood, “Küçük Mustafa”, Encyclopedia of Islam, $2^{\text {nd }}$ edition, C. VII, 1992, s. 712; Sırp prensi Stefan ile yapılan aynı nitelikteki başka bir anlaşma için bkz. Lebenschreibung des Despoten Stefan Lazarević von Kostantin dem Philosophen, Ed. Maximilien Braun, Göttingen, 1956, s. 56-8.

${ }^{85}$ Sphrantzes, s. 1028C: “ 'Birkaç gündür kendimi iyi hissetmiyorum. Ama iyileşmek ve birlikte yeyip içmek ve konuşmak istiyorum' dedi' Ama üç gün sonra öldü.”; Dukas, s. 163.10-14; Dukas'ın kroniğini güvenilir bulan Runciman, yanlışlıkla Mehmed'in ölüm tarihini 1421 yılının Aralık ayına yerleştirmektedir. Bkz. Steven Runciman, The Fall of Constantinople 1453, Cambridge University Press, Cambridge 1965, s. 44. Halkokondyles, sultanın ölümünden bahsetmekte ancak tarih vermemektedir. Bkz. Halkokondyles, C. 2, s. 1.1. Bkz. Ferhan KırlıdökmeMollaoğlu, Laonikos Chalkokondyles'in Kroniği ve Değerlendirmesi (V.-VII. Bölümler), (Ankara Üniversitesi Sosyal Bilimler Enstitüsü Yayınlanmamış Doktora Tezi), Ankara 2005, s. 56.

${ }^{86}$ Mehmed'in ölümü Anonim Grekçe Kısa Kroniklere de (bazıları kronolojik olarak hatalı olsa da) konu olmuştur. Kronik 72a'nın bir notunda herhangi bir tarih verilmeksizin bir önceki notun bir başka olayla ilgili verdiği 6934 (1426) tarihinden aynı zamanda Mehmed'in ölüm yılı olarak bahsedilmektedir. Bkz. Anonim Grekçe Kısa Kronik no. 72a, paragraf 22, s. 564: “ve aynı yılda Sultan Kyritzis öldü ve oğlu Sultan Murad hükümdar oldu)”; Anonim

\author{
History Studies \\ www.historystudies.net
}


gizli tutuldu. Cenazesi mumyalanarak 40-42 gün kadar sarayında muhafaza edildi. Şehzade Murad gelene kadar ahaliye sultan yaşıyormuş izlenimi vermek için yeni bir sefere çıkılacak gibi davranılarak yeniçeriler Anadolu'ya nakledildi. Çünkü sultan Mehmed, zaten sağlık durumu iyice kötüleşince Bayezid Paşa’ya ölümünü ilan etmemesini ve Osmanlı tarihinin ilk örneği olacak bir şekilde en büyük oğlu Murad'ın sorunsuz şekilde tahta çıkmasını sağlamasını emretmişti. ${ }^{87}$ Dukas'a göre: “Amaçları şuydu; civardaki milletler yani Romalılar (Bizanshllar), Sirplar,

Grekçe Kısa Kronik no. 97, paragraf 5, s. 639: “ [Kyritzis öldü 6932 (1424 yllında), 2. indiksiyonda]”. Mehmed'in ölüm tarihini veren kısa kroniklerden yalnızca 91 nolu kronik ve 60a nolu kronikteki iki notta ölüm yılı doğru olarak 6929 (1421) dünya yılına yerleştirilmiştir. Bkz. Anonim Grekçe Kısa Kronik no. 91, paragraf 9, s. 623: "[6928 dünya yılında sultan (Kyritzis, öldü)]. Anonim Grekçe Kısa Kronik no. 60a, paragraf 9'dan naklen Kilıç, a.g.t, s. 166. Buna en yakın tarih, kronik 71a tarafından kaydedilen 6920 (1422) dünya yılıdır. Bkz. Anonim Grekçe Kısa Kronik no. 71a, paragraf 14'ten naklen Kılıç, a.g.t., s. 166. Modern dönemin tarihçileri, Mehmed'in ölüm tarihiyle ilgili farklı görüşler öne sürmektedir. Anonim kroniklerin edisyon kritiğini yapan Schreiner'e göre, doğru kronoloji 6929 dünya yllının 14. indiksiyonu, 21 Mayls 1421 olmalıdır. Bkz. Peter Schreiner, Die Byzantinische Kleinchroniken. Historischer Kommentar, C. II, Wien, 1977, s. 412; Ayrıca bkz. K1lıç, agt, s. 166-171, 378, 389; Mehmed'in ölüm tarihi, Taeschner tarafindan sultanın Bursa'daki mezar kitabesinde Mayıs 1421 olarak okunmuştur. Bkz. Franz Taeschner, "Beiträge zur frühosmanischen Epigraphik und Archäologie" Der Islam, 20 (1932), s. 147-148. Bu

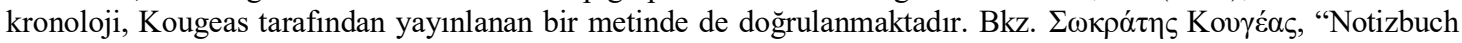
eines Beamten der Metropolis in Thessalonike aus dem. Anfang des XV. Jahrhundert," Byzantinische Zeitschrift, 23 (1919), s. 151-152, no. 80. Bu metin, Mehmed'in ölümü ve aynı zamanda sözde Bizanslı dostlarına karşı gösterdiği düşmanca tavır hakkında daha fazla ayrıntı vermektedir: "21 Mayıs'ta (14. indiksiyonda) 6929 [1421] dünya yllında, Thessaloniki ve Roma (Bizans) topraklarına bask yapan ve endişeye sevk eden Sarakinosların [Agarinoslar/Türkler] lideri dinsiz ve kâfir Sultan Kyritzis [I. Mehmed] büyük [Aziz] Dimitrios'un bir mucizesi sayesinde dizanteriden ve epilepsiye benzer bir hastalıktan öldü." Bu kronolojik not [Chroniken Einzelnotizen (ChronNot) no. 67], Schreiner'in ilgili eserinin ikinci cildinde, 116 nolu kronikten bağımsız bir kaynak olarak ve bunlara ek mahiyetindeki 11 adet kronolojik not arasında ikinci kez yayınlandı. Bu bölüm için bkz. Schreiner, age, C. II, s. 606-623; Bu kaynak hakkında bkz. Kılıç, age, 72-73, özellikle 166. Alderson, Timur'un tarihçisi Ahmed ibn Arabşah'ın Mehmed'in zehirlenerek öldürüldüğüne dair kaydına dikkat çekmektedir. Bkz. Ahmad ibn Arabshah, Tamerlane. The Life of the Great Amir, translated by J. H. Sanders, Luzac and Co., London, 1936, s. 187); Barker, bu kaydı güvenilmez bulmaktadır. Bkz. Barker, age, s. 355, not. 100. Alderson, Mehmed'in ölümünü 26 Mayıs 1421 'e tarihlemektedir. Anthony Dolphin Alderson, The Structure of the Ottoman Dynasty, The Clarendon Press, Oxford, 1956, Tablo XV ve XXV. Barker, bu tarihin Osmanlı kaynaklarından geldiğini tahmin etmekte ve bu tarihler genellikle yanlış olduğunu ileri sürmektedir. Barker, age, s. 355, not. 10. Bu kaynaklara baktığımızda Âşıkpaşazâde, olayı doğru bir şekilde 1421 (H. 824) tarihine, Neşrî ise Haziran 1421 (H. 824) tarihine yerleştirmektedir. Bkz. Âşıkpaşazâde, s. 161162; Neşrî, s. 550-551, Oruç b. Âdil, daha doğru olarak 1421 (H. 824) yılını benimsemektedir. Bkz. Oruç b. Âdil, 53. Hoca Sadeddin ise Âşıkpaşazâde ve Oruç b. Âdil'in kronolojisini takip etmektedir. Bkz. Hoca Sadeddin, s. 115. Tarihî Takvimler ise, Hicrî 824 yılının Receb ayının 8. gününü, (9 Temmuz 1421) Çarşamba gününü vermektedir. Bkz. Osmanlı Tarihine Ait Takvimler, C. 1, düzenleyen Nihal Atsız, İstanbul 1961, s. 103. Taeschner, herhangi bir kaynak belirtmeksizin Mehmed'in ölüm tarihini 4 Mayıs olarak vermektedir. Bkz. Franz Taeschner, "The Ottoman Turks to 1453" Cambridge Medieval History. The Byzantine Empire, C. IV, Bölüm 1: Byzantium and Its Neighbours, $2^{\text {nd }}$ ed., Cambridge University Press, Cambridge 1966, s. 769; Uzunçarşı11, Hicrî 824 yılının Cemaziyelevvel (Mayıs) ayını veren Neşrî, Hoca Sadeddin ve özellikle Şükrullah'ın kayıtlarına dayanarak önce Haziran 1421 tarihini ileri sürdü, ancak daha sonra Mayıs 1421 tarihini benimsedi. Bkz. İsmail Hakkı Uzunçarşılı, Osmanlı Tarihi, C. 1, 5. Baskı, Türk Tarih Kurumu Yayınları, Ankara 1988, s. 373, not. 4; Uzunçarşılı, "Mehmed I”, s. 504; İnalcık’a göre sultan, Receb ayının 25. Günü (25 Haziran 1421) Edirne öldü ve II. Murad, aynı tarihte tahta çıktı. Bkz. İnalcık, "Mehemmed I", s. 977. Ayrıca bkz. İnalcık, "Murad II”, s. 594; Halil İnalcık, “The Ottoman Turks and the Crusades". A History of the Crusades 1329-1451, Ed. Kenneth M. Setton, Madison, 1989, s. 222-310; Halil İnalc1k, Devlet-i 'Aliyye, Osmanlı Imparatorluğu Üzerine Araştırmalar-I, İş Bankası Kültür Yayınları, İstanbul, 2009, s. 90; Halil İnalcık, Kuruluş Dönemi Osmanlı Sultanları (1302-1481), İSAM Yayınları, İstanbul 2010, s. 129; Imber, tarih olarak herhangi bir kaynağa dayanmaksızın 1421 yazını benimsemiş görünmektedir. Bkz. Imber, age, s. 90.

${ }^{87}$ Dukas, s. 167.30: "Mehmed Beg ölünce, daha önce anlattığımız gibi, dört kişi hariç kimse öldüğünü bilmesin diye cenazesini Edirne'de yaptırdığl sarayda, kırk gün boyunca öldü̈̆̈̈ evde defnetmeden sakladılar." Dukas'ın anlatısıyla en çok örtüşen kayıt Âşıkpaşazâde'ye aittir. Buna göre, Sultan, ölümünden önce vezirleri Hacı İvaz Paşa ve Bayezid Paşa'ya oğlu II. Murad tahta çıkana kadar ölümünün gizli tutulmasını vasiyet etti. Sultanın öldügüne dair söylentiler ortaya çıkınca askerler onu görmek için ısrar etti. Onları sakinleştirmek için cenaze tahta oturtuldu ve tahtın arkasına geçen birinin yardımıyla sultanın eli-kolu hareket ettirilerek uzak mesafedeki askerlere yaşadığı izlenimi verildi. Bkz. Âşıkpaşazâde, s. 94. Kılıç’a göre, Osmanlı kroniklerindeki bu farklı kronolojinin nedeni, I. Mehmed'in ölümü ile II. Murad'ın tahta çıkışı arasındaki kırk bir gün süren bu gizleme süresidir. Bkz. Kılıç, agt, s. 170-171.

\author{
History Studies \\ www.historystudies.net
}


Cenevizliler, Venedikliler ve Anadolu'daki Karaman (Beyliği) hükümdarın ölümünü öğrenirlerse, veliaht Murad'ın Pers ülkesinin sınır boylarından gelmesi imkânsız olurdu. Sonuç olarak, orduda tahta veraset konusunda büyük gürültü kopar ve muhtemelen isyan hareketleri ortaya çıkardı. Trakya'nın bazı bölgelerinde Hristiyanların da yapmış olabileceği bir şeyi Karaman'ın (Beyliği) da pişmanlık duymadan yaptığı bir yağma vakası oldu. Ve bu tür olaylar, Türklerin zayıflamasına ve Romalıların (Bizanslıların) toparlanmasına yol açacaktı."88

Murad'ın ilk önce sağ salim Bursa'ya gelmesi ve rahat bir şekilde tahta geçmesi amaçlanmışt1. ${ }^{89}$ Mehmed'in vezirleri sancak beyi olarak Amasya'da bulunan Murad'a babasının vefatını bildirmek için ${ }^{90}$ bir haberci gönderdiler. Kırk gün sonra haberci, Murad'ın Bursa'ya gelişini vezirlere haber verdi ve babasının cenazesi için verdiği emirleri ana hatlarıyla anlatan mektuplar gönderdi. ${ }^{91}$ Dukas'ın anlatımından anladığımıza göre Mehmed'in vezir-i âzâmı Bayezid Paşa da Murad'ı destekliyordu ve onun Bursa'da tahta çıkmasında önemli bir rol oynad..$^{92}$ Leontaris'in elçilik görevinden bahseden Sphrantzes, Sultan Mehmed'in dört adam1 hariç, tüm hizmetkârları gibi Bizans elçisi Leontaris de bu gelişmelerden habersizdi. Ona sultanın ölümü ve taht değişikliği hakkında bilgi vermediklerinden ve isteklerini dinlemek için Mehmed tarafından davet edilmediği için kaldığ 1 evde kafası sorularla dolu beklediğini ekliyor. Ancak Leontaris, yine de kısa süre sonra sultanın ölümünden haberdar oldu. "Ama Konstantinopolis'e giden yolları gizlice kestikleri için, Bizans başkentine mektuplarla ard arda birçok haberci göndermesine rağmen, bunların geçişlerine izin verilmedi ve böylece günler geçti." Ancak Leontaris, bir adamıyla Karadeniz kıyısındaki Mesembria liman kentine giden başka bir yoldan imparatora mesaj göndermeyi başard1. Ancak bu belirsizlik döneminde Konstantinopolis'te çok fazla tedirginlik hâkimdi. O dönemde kenti kasıp kavuran veba salgını nedeniyle Peripleptos manastırına çekilmiş olan Manuil, onu şansı varken sultanı yakalayıp öldürmediği için suçlayan savaş yanlısı hizibin suçlamalarına maruz kald1. ${ }^{93} \mathrm{Bu}$ arada Mehmed'in oğlu Murad (1421-1451) ölümünden kırk gün sonra tahta çıktı. Dukas'a göre, babası öldüğünde Amasya'da sancak beyi olan Murad'ın görev yerinin uzakta olması, Bayezid Paşa ve vezir İbrahim Paşa'nın desteği sayesinde doğrudan tahtı devralmasında ciddi bir engel oluşturmadı. Bizanslı tarihçiye göre, I. Mehmed'in maiyyetindeki birbirine rakip gruplar, farklı şehzadeleri desteklediler. Nitekim babası öldüğünde Murad, Bayezid Paşa ve vezir İbrahim Paşa tarafından bilgilendirildi ve vakit kaybetmeden Amasya'dan Bursa'ya geldi ${ }^{94}$ ve 25 Haziran 1421'de Osmanlı tahtına çıktı. ${ }^{95}$

Bizanslılar, bu olaylar karşısında bir yol ayrımındaydı ve hangi yolu izleyeceklerine karar vermek zorundaydı: ya Mehmed'in en büyük oğlunun tahta çıkışını kabul edecekler ve Osmanlılarla barışı koruyacaklar ya da Osmanlı iç savaşı sırasında İmparator Manuil'in uyguladığı politikayı izleyerek bir taht müddeisini iktidarı elinde tutan sultana karşı kışkırtarak destekleyeceklerdi. VIII. İoannis ve bazı Bizans soyluları, o sırada Konstantinopolis'te ortaya çıan veba salgını nedeniyle hem II. Murad'ın tahta çıkışı hem de Manuil'in manastıra çekilmesinden yararlanmak istediler. Lachanas Palaiologos ile Theologos Korakas, Bursa'ya elçi

\footnotetext{
${ }^{88}$ Dukas, s. 167

${ }^{89}$ Dukas, s. 169.9-15.170.27-12.

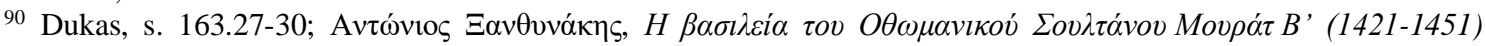

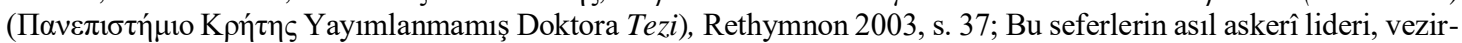
i âzâm Bayezid Paşa idi...” Bkz. Halil İnalcık, agm, s. 598.

${ }^{91}$ Dukas, s. 169.16-23.

92 Dukas, vezir-i âzâm Bayezid Paşa'nın şehzade Murad'1 desteklediğine açıklık getirmektedir. Murad'ın Bursa'ya gelişini bir mektupla duyurması üzerine Bayezid Paşa'nın mektupları büyük bir mutlulukla aldığını yazmaktadır: “Bayezid, o zaman mektupları büyük bir sevinç ve içi rahatlamış olarak aldl." Bkz. Dukas, s. 169.24-25.

${ }^{93}$ Sphrantzes, s. 1028C-1029A.

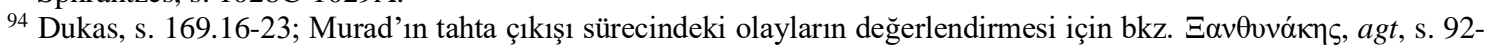
93.

${ }^{95}$ Çetin Varlık, Germiyanoğulları Tarihi (1300-1429), Ankara, 1974, s. 91.
}

\author{
History Studies \\ www.historystudies.net
}


olarak gönderildi. Elçilerin görevi, iki mesajı iletmekti: ilki Mehmed'in ölümü için imparatorun taziye mesajını iletmek ve tahta çıkışı dolayısıyla Murad'ı tebrik etmek. İkinci mesajın devamı, VIII. İoannis'in genç sultandan bazı tavizlerde bulunmasını sağlamaya çalıştığını gösterir cinstendir: Murad'a babası gibi Bizans ile iyi ilişkilerin devamını istiyorsa, I. Mehmed'in iradesine boyun eğmesi, babasının vasiyeti gereği iki kardeşi Yusuf ve Mahmud'u Bizans vesayetine vermesi gerektiğini bildirerek iki küçük șehzadeyi istedi. Aksi takdirde Bizans imparatoru, Mustafa'yı salıverme ve onu Rumeli'ye hükümdar yapma hakkına sahip olacaktı. Her halükarda elçiler, Mehmed'in oğullarını teslim etmeyi reddeden, ancak önceki antlaşmalara riayet edeceklerini ve ortak sınırlardaki durumu değiştirmek üzere herhangi bir girişimde bulunmayacakları konusunda güvence veren Bayezid Paşa ile görüştüler. Bir başka rivayete göre ise Sultan Mehmed, Osmanlı Devleti'nin Rumeli topraklarını Murad'a, Anadolu'yu ise Mustafa'ya bırakmıştı. Belki de bu, imparatorun sultanla müzakere ettiği anlaşmanın bir taslağıydı ve bir şekilde Manuil'in Mehmed'in ölümünden önce Leontaris'i Edirne'ye göndermesinin başlica nedeniydi. Mehmed' in vasiyetinin tam içeriğinin ne olduğu ile ilgili yeterli kanıtımız yoktur. Yine de şüphesiz I. Mehmed, geçmişte bizzat tecrübe ettiği bir iç savaştan kaçınmak için Bizans tarafına bazı tavizler vermeyi göze almıştı. ${ }^{96}$

Ancak II. Murad, beklenenin tersine iktidara gelir gelmez iki kardeşini Tokat'a sürgüne göndererek saf dışı bırakınca VIII. İoannis'in beklentileri suya düştü. ${ }^{97}$ Yeni sultan, iki küçük şehzadenin muhtemel destekçilerine karşı onları uzaklaştırmak için acele etmiş olmalıdır. Nitekim o sırada Konstantinopolis'e yolunda olan Burgundiyalı elçi Ghillebert de Lannoy, o sırada isimlerini vermediği "üç rakip şehzadenin (seigneurs) tahtı ele geçirmek için birbirleriyle çatıştı̆̆ını” aktarmaktadır. Elçinin Konstantinopolis'e ulaşması Kiliselerin Birliği meselesini müzakere eden papalık elçilerinin kentteki ikametiyle aynı zamana denk geldi. Papalık elçisi Antonios da Massa, Eylül ve Ekim 1422 tarihlerinde Konstantinopolis'te bulunuyordu. ${ }^{98}$

Osmanlı vakanüvistleri, II. Murad'ın zorluk çekmeden I. Mehmed'in yerine geçtiği izlenimini vererek şehzadeler arasındaki taht mücadelesini gizlemektedir. Oysaki Hicrî 824 (Ocak-Aralık

\footnotetext{
${ }^{96}$ Dukas, s. 165-167 ve 173; Halkokondyles, I, s. 203; Barker, age, s. 356, no. 102; İnalcık, "Murad II”, s. 598-599; Imber, age, s. 91; Colin Heywood, Dukas'ın imalarından yola çıkarak, Mehmed'in ölümünden sonra başka iç savaşları önlemeyi amaçladığını, bu yüzden devletini iki oğlu arasında paylaştırdığını Ayrıca daha küçük yaştaki iki şehzadesini de Bizans imparatorunun vesayeti altına göndermek istediğini düşünmektedir. Bkz. Colin Heywood, "Küçük Mustafa" Encyclopedia of Islam, $2^{\text {nd }}$ ed., C. VII (1992), s. 711-712; Ksanthinakis, Heywood'un teorisini

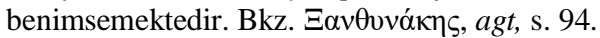

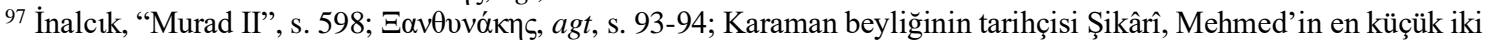
oğlunun Murad'ın tahta çıkışından kısa bir süre sonra Bursa'da öldürüldüğünü, ancak Küçük Mustafa'nın hayatta kaldığını kaydetmektedir. Bkz. Şikârî, Karamannâme [Zamanın kahramanı Karamanîler'in tarihi], Ed. Metin Sözen-Necdet Sakaoğlu, İstanbul 2005, s. 62.

${ }^{98}$ Ghillebert de Lannoy'un anlatısı için bkz. Oeuvres de Ghillebert de Lannoy, Voyageur, Diplomate et Moraliste, Ed. H. Potvin, Louvain 1878, s. 59, 65; Imber, age, s. 91; Elizabeth A. Zachariadou, "Ottoman Diplomacy and the Danube Frontier," HUS, Okeanos, Essays Presented to Ihor Sevcenko, C. VII (1983), s. 687; Barker, age, s. 327, s. 339, 367; Setton, age, s. 42-43; Görünen o ki Ghillebert de Lannoy, Murad'in önce küçük kardeşleri Mahmud ve Yusuf, sonra da amcası Düzmece Mustafa'dan kurtulduğu dönemde Tuna'yı geçmeyi başarmıştı. Ghillebert de Lannoy'un nehri

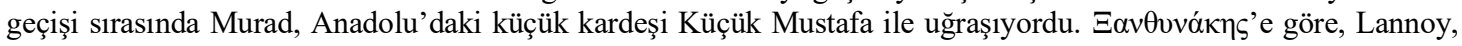
üç Osmanlı hâkimi ve dolayısıyla üç rakip arasında yanlışlıkla Düzmece Mustafa'ya eşlik eden Cüneyd'i de göstermiş olmalıdır. Cüneyd, Osmanlı tahtı üzerinde bir hak talebinde bulunan bir şahıs olmadığından Ghillebert de Lannoy’un kaydındaki "birbirlerine rakip üç Osmanlı hâkimi (trois seigneurs)" ibaresinden sadece Murad ve Düzmece Mustafa'yı anlamalıyız. Tarihçi, ayrıca "trois seigneurs" ibaresiyle Ghillebert de Lannoy'un Murad ve Düzmece Mustafa'yı ve Küçük Mustafa'yı da kastedemeyeceğini, çünkü Küçük Mustafa'nın bu tarihte isyan

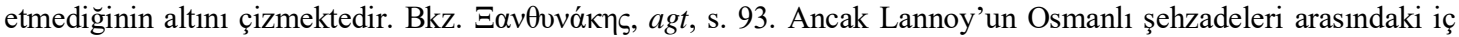
savaşla ilgili anlatısı, Düzmece Mustafa'nın ortadan kaldırılmasından ve Küçük Mustafa'nın ortaya çıkmasından hemen sonraki dönem hakkında ise farklı tarihlerde meydana gelen iki Mustafa ile ilgili olaylar yanlışlıkla birleştirilmiş olmalıdır. Bu durumda, Ghillebert de Lannoy’un Bizans başkentine giderken geçtiği Tuna' da güvenlik sorunu olması söz konusu olmayacak; Düzmece Mustafa çoktan ortadan kaldırılmış olacak ve Küçük Mustafa'ya karşı Anadolu'da savaş yürütülebilecekti.”; Ayrıca bkz. Matschke, age, s. 117.
}

\author{
History Studies \\ www.historystudies.net
}


1421) ve 825 (Aralık 1421-Aralık 1422) tarihli Osmanlı takvimleri, sultanın tahta çıkar çıkmaz "kardeşleriyle çatıştığı" Murad'ın küçük kardeşlerini Tokat'ta hapsettiğini aktarmaktadır. ${ }^{100}$ Murad, büyük olasılıkla kardeşlerini ihtiyatla etkisiz hale getirerek, konumunu otoritesine meydan okuyabilecek kişilerin gölgesinden kurtardı. Tüm bunlar olurken İsfendiyar Bey'in neden olduğu rahatsızlığın şehzadeler krizine denk gelmesi dikkat çekmektedir. İsfendiyar, geçmişte yaptı̆̆ 1 gibi, Osmanlı vassallığından kurtulmak istedi ve Çankırı (Gangra) bölgesinin Osmanlı komutanı Kasım Bey ile oğlunu Tosya'daki Kalecik'ten kovdu. Murad'ın ordusu, onu Sinop'a kadar takip etti. Barış, ancak Anadolu'nun diğer Türk beyliklerinin müdahalesi ve arabuluculuğu ile 1421 sonbaharında veya kışında imzalanan bir antlaşmayla gelecekti. ${ }^{101}$

$\mathrm{Bu}$ arada küçük şehzadelerinin vesayetini üstlenme girişiminde başarısız olan VIII. İoannis, 1416'dan beri gözetim altında tutulan Mustafa ile ve Cüneyd Bey'in serbest bırakmasını emretti. Bu olay, Mustafa'nın tahta çıkarsa Gelibolu gibi önemli bölgeleri Bizans'a iade edeceğine söz vermesinden sonra gerçeklești. Bu bahsin detayları Halkokondyles'in anlatısında saklıdır: "Imparator Ioannis, biri Rumeli diğeri Anadolu'da birbirine rakip iki sultanın olduğu bir statükoda meseleler üzerinde her zaman aktif rol oynama seçeneğine sahip olacağını düşündü. Gerçek devlet yönetimi, Murad ile Mustafa arasında paylaşılacaktı."102 Bizanslılar, Süleyman Çelebi'nin 1402 y1lında kendilerine sunduğu teklife çok benzer vaatlerde bulunan Mustafa ile müzakere etmeye başladılar. Pseudo-Ruhi'nin anlatısı ile paralellik gösteren Dukas ve Anonim Grekçe bir Kısa Kronik'e göre, Mustafa, oğlunu imparatorun vesayetine vermeyi ve Karadeniz, Halkidiki ve Gelibolu'daki bazı bölgeleri teslim etmeyi kabul etti. ${ }^{103}$

Bizans imparatorları Mustafa ile müzakere ederken Bursa'da bulunan Sultan Murad, Bayezid, Çandarlı İbrahim ve Hacı İvaz Paşalar divanda bir araya geldiler. Mustafa'nın Rumeli'ye ilerleyişini engelleyecek önlemleri tartışırlarken Çandarlı İbrahim ile Hacı İvaz Paşa, Rumeli beylerbeyi olduğu ve o zamana kadar bölgeden çok istifade eden bir kişi olarak bu göreve Bayezid Paşa'nın atanması gerektiğini öne sürdüler. ${ }^{104}$ Anlaşılan iki vezir, vezir-i âzâm Bayezid'ten pek haz etmiyordu. Sonuçta, Murad, bu görevi Bayezid Paşa'ya verdi; ondan imparatorla bir anlaşmaya vararak Rumeli'ye dönmesini istedi. Anlaşıldığı üzere Murad'ın imparatorun Mustafa ile yaptığı anlaşmadan haberi olmuştu ve bu nedenle Bizans idaresinin "tarafsızlığını" elde etmek bazı fedakârlıklarda bulunmaya hazırdı. Bayezid Paşa, Konstantinopolis civarındaki Hieron Stomion'a geldiğinde, elçilerini bir anlaşma sağlamak üzere Bizans başkentine gönderdi. ${ }^{105} \mathrm{Bu}$ elçiliğin ayrıntılarını veren Halkokondyles'e göre: "(Bayezid), soylu ailelerden on iki çocuğu imparatora rehin olarak vermeyi, iki yüz bin akçe ödemeyi ve Gelibolu kenti dışında çevresindeki bazı bölgeleri teslim etmeyi teklif etti. Bunun karşılığında Bizanslılardan Mustafa'yı desteklememelerini istedi." ${ }^{106}$ Halkokondyles, vezir-i âzâmın imparatora para ve hatta iki prensin

\footnotetext{
${ }^{99}$ Victor Louis Ménage, “The Annals of Murad II,” Bulletin of the School of Oriental and African Studies, C. 39 (1976), s. 573: “... $<$ Murad $>$ kardaşlart ile cenk etdi."

100 Âşıkpaşazâde, Tevârih-i Âl-i Osman, Âli Bey neşri, İstanbul 1332, s. 107.

101 İnalcık, "Murad II", s. 599; Yaşar Yücel, XIII.-XV. Yüzyıllar Kuzey-Batı Anadolu tarihi. Çoban-oğulları Candaroğulları Beylikleri, Türk Tarih Kurumu Yayınları, Ankara 1980, s. 95.

${ }^{102}$ Halkokondyles, II, s. 2. Kısmî Türkçe çevirisi için bkz. Ferhan Kırlı̈ökme Mollaoğlu, Laonikos Chalkokondyles'in Kroniği ve Değerlendirilmesi (V.-VII. Bölümler), (Ankara Üniversitesi Sosyal Bilimler Enstitüsü, Yayımlanmamış Doktora Tezi), Ankara 2005.

${ }^{103}$ Dukas, s. 181; Ruhi Çelebi’ye atfedilen Anonim Kronik için bkz. Pseudo-Ruhi, "Ruhî Tarîhi - Oxford nüshası", Ed. Yaşar Yücel - Halil Erdoğan Cengiz, Belgeler, C. XIV/18 (1989-1992), s. 435; Barker, age, s. 356, no. 102; Imber, age, s. 91.

104 Âşıkpaşazade, s. 96; Neşrî, s. 557; Anonim Osmanlı Kroniği (1299-1512), Ed. Necdet Öztürk, İstanbul 2000, s. 6667.

105 Dukas, s. 187; Sphrantzes, 1029C; Pseudo-Ruhi, s. 435. Hieron Stomion (Güzelcehisar) için bkz. Semavi Eyice,

“Anadolu Hisarı”, Türk Diyanet Vakfi İslam Ansiklopedisi, C. III (1991), s. 147-149.

${ }^{106}$ Halkokondyles, C. II, 2; Barker, age, s. 356 no. 102; İnalcık,"Murad II”, s. 599.
}

\author{
History Studies \\ www.historystudies.net
}


rehine olarak gönderilmesinin yanında Gelibolu yarımadasının bir kısmının teslimi için söz verdiğini kaydetmektedir. ${ }^{107}$

Ghillebert de Lannoy'un anlaşmanın ayrıntılarıyla ilgili anlatısından ${ }^{108}$ anlaşıldığına göre İmparator Manuil'in Mustafa meselesine yaklaşımı oğlu VIII. İoannis'ten farklıydı. Yaşlı imparatorun Bayezid Paşa'nın sözlerine ciddi itirazları vardı itiraz etti ya da belki de bu meselede daha dikkatli davranmak istiyordu. Anlaşıldığına göre Manuil, Mustafa ile müzakereleri "tehlikeli" olarak değerlendiriyordu. Ayrıca "devlet hazinesini ve yeniçerileri kontrolü altında tuttuğu için” Murad'ı Mustafa'ya tercih ediyordu. Ancak sonunda hastalığını ve yaşlılığını neden göstererek idareden elini eteğini çekti ve bu işlerle uğraşmayı oğlu İoannis'e bıraktı. ${ }^{109}$

Bayezid Paşa'nın misyonu VIII. İoannis'in tarafsızlı̆ıını elde edemediğinden başarısız oldu. Çünkü Bizans kaynaklarına göre genç imparator çoktan kararını vermişti. Artık tamamen tek başına hareket edebilecek duruma gelen VIII. İoannis, vakit kaybetmeden işe koyuldu. Şehzade Mustafa'yı destekleme kararı aldı ve gerekli önlemleri almaya başladı. Dimitrios Leontaris'i donanma komutanı olarak atadı ve Mustafa ve Cüneyd'in serbest bırakılması emriyle onu Limnos adasına gönderdi. Sultan Bayezid'in öz oğlu olduğu için Mustafa'yı da hükümdar yapması talimatını verdi. ${ }^{110}$

Genç imparatorun bu hamlesiyle Mustafa'yı sadece geçici bir oyalama olarak değil, Mehmed'in vasiyetinin şartlarını yerine getirmesini istediği II. Murad'ın iktidarına karşı sürekli bir tehdit aracı olarak kullanmak istediği anlaşılabilir. İoannis, Osmanlı Devleti idaresinin ikiye bölünmesini ve böylece zayıflatılmasını amaçlıyordu. Bunun için de Bizans açısından zararsız gördüğ̈̈ “Düzmece” Mustafa'nın Rumeli'nin idaresini almasını istiyordu. Onu kontrol edebildiği sürece Murad'ın Anadolu'daki hâkimiyetini de zayıflatmış olacaktı. Bu yolla Osmanlı sultanının uzaktaki ve Karaman Beyliği gibi en yakınındaki rakipleriyle de sorunlarının devamını da sağlayacaktı. Bu nedenle Mustafa'nın 1421 yazında II. Manuil ve VIII. İoannis ile imzaladığ 1 antlaşma, onun iktidarını (Anadolu'ya geçmemek kaydıyla) Rumeli ile sınırlıyordu. ${ }^{111}$ Dukas'a göre Mustafa, aynı sözleşme uyarınca oğlunu rehin olarak Bizans imparatoruna teslim etti. İlaveten, Tesalya bölgesini Bizans'a devretmeye söz verdi. Bizans'a Tesalya'yı (esasen Thessaloniki ve çevresini) Hierissos ve Aynaroz'a kadarki bölgeyi, Karadeniz'in Vlah ülkesi sınırlarına (bugünkü Bulgaristan) kadarki kıyı bölgesini teslim etme sözü verdi. Bizans idaresi, XIV. yüzyıldan beri Gelibolu'nun kendisine iadesini talep etmekteydi. ${ }^{112}$

Mustafa, Eylül ayında Dimitrios Leontaris'in eşliğinde Türk ve Bizans birlikleriyle birlikte gemilerle Gelibolu'ya geçirildi. ${ }^{113}$ Cüneyd Bey, Mustafa'ya Bizans gemileriyle Gelibolu'ya nakledildiği sırada şehzadeye katıldı. ${ }^{114}$ İmparator İoannis de Mustafa ile yaptı̆̆ 1 anlaşmayı onaylamak için Gelibolu yarımadasına geldi. ${ }^{15}$ Şehzadeye eşlik edenlerin arasında Türk ve Bizans birlikleri de vardı. ${ }^{116}$ Bizans donanması Gelibolu limanına girince Murad'ın Şah Melih

\footnotetext{
${ }^{107}$ Halkokondyles, C. II, Budapest, 1927, s. 2.

108 Elizabeth A. Zachariadou, "Ottoman Diplomacy and the Danube Frontier (1420-1424)", Harvard Ukranian Studies, C. VII (1983), s. 685.

${ }^{109}$ Halkokondyles, C. II, s. 3; Sphrantzes, 1029A-B; Barker, age, s. 355-356.

${ }^{110}$ Dukas, XXIII, s. 175.

${ }^{111}$ Zachariadou, agm, s. 687. Ne yazık ki, antlaşmanın metni günümüze kadar ulaşamamıştır.

112 Dukas, s. 181.13-14. Ayrıca bkz. İnalcık, "Murad II", s. 599; Burgundiyalı elçi Ghillebert de Lannoy da Dukas'ın Mustafa'nın imparatora bazı toprakları teslim edeceğine dair verdiği vaatler hakkındaki anlatısını doğrulamaktadır. Bkz. Lannoy, s. 66. Ayrica bkz. Matschke, age, s. 102-103 ve 117, not. 427.

${ }^{113}$ Dukas, s. 181.20-21: “... Mustafa ve Cüneyd) de yelkenlerini kanatlandırıp Gelibolu'ya yelken açtılar.”

${ }^{114}$ Sphrantzes, s. 1029A-B.

115 Sphrantzes, 1029B-C; Halkokondyles, C. II, s. 3; Barker, age, 357.

${ }^{116}$ Dukas, s. 175.12-15; Thessaloniki başpiskoposu Symeon'un II. Murad dönemindeki olaylar ve özellikle "Düzmece" Mustafa'nın isyanı hakkındaki kayıtları için ayrıca bkz. Kırlı̈ökme-Mollaoğlu, agt, s. 59-75.
}

\author{
History Studies \\ www.historystudies.net
}


Bey komutasındaki komutanları kaleyi emniyete aldılar. ${ }^{117}$ İlk olarak Cüneyd ve Bizans birlikleri karaya çıktı. Ardından Mustafa, Gelibolu halkını topladı ve onlara Bayezid'in öz oğlu ve dolayısıyla gerçek sultanları olduğunu ilan etti. Ayrıca kendisine Edirne'ye giden yolun açılması şartıyla ahaliye bir baba gibi hoşgörülü davranacağını bildirdi. Bunun üzerine Gelibolu çevresindeki bölgelerden gelen Türkler ona biat ettiler. Bununla birlikte Gelibolu kentinin ahalisi teslim olmadı ve Mustafa, Edirne'ye ilerlemek için hazırlanırken Leontaris kaleyi kuşatmaya devam etti. ${ }^{118}$

Mustafa'nın Rumeli'deki ilk başarısını elde etmesi üzerine Bayezid Paşa Rumeli ordusunu topladığ 1 Edirne'ye geldi ve kente yaklaşan Mustafa ile savaşmak için yola çıktı. Şehzade, birlikler karşı karşıya geldiğinde ve muharebe başlamak üzereyken yüksek bir yere çıktı ve Bayezid'in ordusundaki Rumeli uç beylerine seslendi. Gerçek bir şehzade olduğunu ve Bayezid Paşa'nın iddia ettiği gibi bir "sahtekâr" olmadığını söyledi. Musa'nın evvelce yaptığı gibi, bu adamların savaşçı ruhuna hitap ederek onları hiçbir şeyden mahrum etmeyeceğine ve sahip olduklarına yenilerini ekleyeceğine söz verdi. Bu konuşmanın ardından uç beyleri Mustafa'ya biat ettiler. Bayezid de ona itaat etti, ancak daha sonra Cüneyd'in emriyle yakalanıp idam edildi. Mustafa, Edirne'ye gitti ve sultan ilan edildi (Ekim 1421). ${ }^{119}$ II. Murad, çok zor bir durumda kald1, çünkü rakibi dış müttefiklerin yanı sıra, Rumeli'deki akıncı beyleri gibi iç güçlerin de desteğini kazanmıştı. Trakya ve Makedonya'nın fatihi Evrenos Gazi'nin Yenice-i Vardar'daki oğullarını yanına çeken ve Serres'i (Siroz) ele geçiren Mustafa, ${ }^{120}$ burada kendi adına sikke darp ettirdi. ${ }^{121}$

Mustafa'nın tahta çıkması haberleri üzerine Gelibolu ahalisi de ona biat etti ve Dimitrios Leontaris de kenti devralmak için hazırlıklara başladı. Mustafa'dan önce kente Cüneyd Bey geldi. Türk ahalinin bu beklenmedik işgal karşısında şaşkınlık içinde olduğunu görünce kaleyi teslim etmeyeceğini, çünkü bunun Gelibolu halkının iradesine aykırı olacağını belirtti. Cüneyd kenti teslim etmeyi reddedince Leontaris, Mustafa'ya başvurdu. ${ }^{122}$ Halkokondyles, "Mustafa'nın aslında Gelibolu'yu teslim etmek istediğini” nakletmektedir. ${ }^{123}$ Ancak Sphrantzes'in yazdığına bak1lırsa "Bütün Türkler, Gelibolu'nun kendilerine ait olduğuna inanıyordu."124

1421 sonbaharının sonlarına gelindiğinde artık Mustafa, Balkanlar'daki Osmanlı topraklarına tek başına hükmediyordu. Gelibolu'nun teslim olmasının ardından Osmanlı donanması ve Rumeli ile Anadolu arasındaki deniz yolu da onun kontrolüne geçmişti. ${ }^{125}$

Murad ise o sırada Mustafa'nın denizdeki avantajlı durumuyla başa çıkabilmesine destek olabilecek bir müttefikle temas halindeydi. Bu kişi, Yeni Phokaia'nın (Foça) Cenevizli podestası Giovanni Adorno idi. Osmanl1-Ceneviz görüşmeleri muhtemelen Haziran ayında Adorno'nun Bursa yolundayken Murad'ı Rumeli'ye geçirmeyi teklif etmesiyle başlamıştı. Sultan Murad, Gelibolu'nun tesliminden sonra Taharetsiz Hatib adlı komutanlarından birini elli bin akçeyle Adorno'ya göndererek bir donanma kurmasını istedi. Ayrıca Adorno'nun Phokaia'da işlettiği şap madeni üzerindeki ödenmemiş borcunu da iptal etmeye söz verdi. ${ }^{126}$ Sultan bu dönemde başka diplomatik adımlar da attı. Gönderdiği elçiler, Konstantinopolis'teki Venedik balyozu Benedetto

\footnotetext{
117 Pseudo-Ruhi, s. 435.

${ }^{118}$ Dukas, s. 181-183; İnalc1k, "Murad II", s. 599; Imber, age, s. 91.

${ }^{119}$ Dukas, s. 187-195; Halkokondyles, C. II, s. 4; Âşıkpaşazâde, s. 164-165; Neşrî, s. 557-559;

Anonim Osmanlı Kroniği, s. 67; Imber, age, s. 92; Heywood, "Mustafa”, s. 711.

${ }^{120}$ Colin J. Heywood, "Mustafa Çelebi. Düzmece” Encyclopedia of Islam, $2^{\text {nd }}$ ed., C. VII (1992), s. 711.

121 Âşıkpaşazâde, s. 157.

${ }^{122}$ Dukas, s. 195-197; Barker, age, s. 358; İnalcık, "Murad II”, s. 599; Imber, age, s. 92.

${ }^{123}$ Halkokondyles, II, s. 4; Barker, age, s. 358, not. 104.

${ }^{124}$ Sphrantzes, s. 1029B-C; Halkokondyles, C. II, s. 4; Dukas, s. 175, 181-201; Barker, age, s. 358; Imber, age, s. 92.

125 Dukas, s. 201; Âşıkpaşazâde, s. 96-97; Neşrî, s. 558-559; İnalcık, "Murad II", s. 600.

${ }^{126}$ Dukas, s. 209; Âşıkpaşazâde, s. 99-100; Neşrî, 565; Imber, age, s. 93.
}

\author{
History Studies \\ www.historystudies.net
}


Emo ve Sırp Despot Stefan Lazareviç ile bir anlaşma yaptılar. ${ }^{127}$ Bunun yanında yeni vezir-i âzâmı Çandarlı İbrahim Paşa'yı Bizans idaresinin Gelibolu'yu teslim etmeyi reddeden Mustafa'dan rahatsız olduğunu bildiği için Konstantinopolis'e gönderdi. 1421-1422 kışında Çandarlı İbrahim, imparatorla görüştügünde geçmişte yaşanan sıkıntılardan Bayezid Paşa'yı sorumlu tuttu ve İmparator Manuil'in II. Murad'a bir zamanlar babası I. Mehmed'e ettiği gibi yardım edebileceğini ifade etti. Sonra birkaç ay önce Bayezid'in yaptı̆̆ gibi I. Mehmed'in küçük şehzadelerini ve Gelibolu'yu imparatora teslim etmeyi reddetti. ${ }^{128}$

Bu sırada Mustafa, Anadolu'ya geçmeye karar verdi ve İoannis ile ilişkilerini düzeltmek için Konstantinopolis'e elçiler gönderdi. Şehzadenin elçileri imparatorla görüştüklerinde Mustafa'nın Bizanslılarla dostluğunu sürdürmek ve Murad'a karşı kazandığı zaferden sonra Gelibolu'dan feragat etmeyi istediğini bildirdiler. Bu sırada Murad'ın elçisi İbrahim Paşa da hâlâ Konstantinopolis'te idi. Bu nedenle II. Manuil ve VIII. İoannis, bir süre her iki tarafla da müzakere ettiler. İki imparatorun Osmanlı Devleti'nin yönetimini iki sultan arasında bölüştürme yönündeki ilk planı, Murad ile Mustafa'nın birbirlerine saldırmak için hazırlık yapmaları nedeniyle başarısız olmuştu. Mustafa, bu planın bir parçasını oluşturan Gelibolu'yu teslim etmeyi teklif ediyordu. Bunun üzerine iki imparator Mustafa'yı desteklemeye karar verdi ve İbrahim Paşa'yı geri gönderdiler. Anlaşılan Mustafa'nın elçileri anlaşmanın diğer ayrıntılarını görüşmek için Konstantinopolis'te kalmıştı. ${ }^{129}$

20 Ocak 1422 tarihinde Mustafa ve Cüneyd Bey, büyük bir orduyla Anadolu'ya geçerek Bursa'ya doğru ilerlediler. Bu arada Sultan Murad ile vezirleri, Mustafa'nın ordusundaki bölünmelerden nasıl yararlanacaklarını istişare ettiler. Daha sonra Bursa'dan ayrılarak Mustafa'nın üç gün sonra dağlık bir geçitten geçerek ulaştığ ${ }_{1}$ Ulubad civarına geldiler. ${ }^{130}$ Bunun üzerine Murad, Cüneyd Bey’e kardeşi Hamza ile bir mesaj göndererek Aydın'a dönmesine, kendisine bir Osmanlı vassalı olarak hüküm sürmesine izin vereceğini bildirdi. Cüneyd, Hamza'ya inanarak Mustafa'nın ordugâhını terk etti. ${ }^{131}$

Sultan Murad, rakibiyle karşı karşıya gelmeden önce Rumeli uçbeylerini kendi tarafina çekmek için uzun süredir Tokat'ta hapiste tutulan Mihaloğlu Mehmed Bey'i serbest bıraktı. Rumeli beyleri nezdinde büyük bir saygınlığa sahip olan Mehmed Bey, savaş öncesinde tüm uç beylerine adlarıyla seslendi ve onları ihanetle suçladı. Onları sultan Murad'ın saflarına katılmaya davet etti. Onun sesini duyan beylerin çoğu Murad'ın tarafina geçmeye karar verdiler. ${ }^{132}$ Diğer yandan Murad'ın Konstantinopolis'ten dönen elçileri Mustafa'nın ordugâhına imparatorla bir anlaşma yaptıklarına, ne imparatorun ne de Bizanslıların Rumeli'ye geri dönmesine izin vermeyeceğine dair haber gönderdiler. Mustafa'nın Konstantinopolis'teki elçileri henüz geri dönmediği için Rumeli beyleri bu haberlere inandılar. ${ }^{133}$ Sonunda Sultan Murad ile vezirleri amaçlarına ulaştı: Cüneyd Bey ve uç beyleri Mustafa'yı terk ederek Rumeli'ye kaçtı. Bu arada Adorno, vakit kaybetmeden Murad'1 Ceneviz gemileriyle Edirne'ye ilerleyeceği Gelibolu'ya geçirdi. Murad'ın birlikleri sıkı bir takipten sonra Mustafa'yı ele geçirdiler (Ocak/Şubat 1422). ${ }^{134}$

\footnotetext{
${ }^{127}$ Halil İnalcık, "The Ottoman Turks and the Crusades (1329-1451)", s. 255; İnalc1k, "Murad II", s. 600; Stefan Lazareviç, Yıldırım Bayezid'in Emrinde Bir Sırp Despotu, çev. Hüseyin Mevsim, İstanbul 2008, s. 88-89.

${ }^{128}$ Dukas, s. 203; Barker, age, s. 358; İnalcık, "Murad II”, s. 599-600.

${ }^{129}$ Dukas, s. 203; Halkokondyles, C. II, s. 5; Barker, age, s. 358, no. 105; İnalcık, "Murad II", s. 600.

${ }^{130}$ Dukas, s. 213; Âşıkpaşazâde, s. 97-98; Neşrî, s. 558-559; Anonim Osmanlı Kroniği, s. 68; Imber, age, s. 92.

${ }^{131}$ Dukas, s. 215-221; Imber, age, s. 93; Melikof, "Djuneyd", s. 599.

132 Âşıkpaşazâde, s. 97-98; Neşrî, s. 559-561; Anonim Osmanlı Kroniği, s. 68-69; Imber, age, s. 92-93.

${ }^{133}$ Halkokondyles, C. II, s. 5-6.

${ }^{134}$ Dukas, s. 223-229; Halkokondyles, C. II, s. 6-7; Âş1kpaşazâde, s. 99-100; Neşrî, s.563-565; Imber, age, s. 93-94; Heywood, Mustafa'nın Vlah ülkesine ve oradan da Kefe'ye kaçtı̆̆ını ileri sürmektedir. Bkz. Heywood, "Mustafa", s. 711.
}

\author{
History Studies \\ www.historystudies.net
}


"Düzmece" Mustafa'nın idam edilerek ortadan kaldırılmasından sonra II. Murad tek başına sultan oldu. Bir süreliğine her şeyi kaybetme tehlikesiyle karşı karşıya kalan sultan 1422 yılında Konstantinopolis'e bir cezalandırma seferine girişse de bu kez Bizans idaresinin onu kuşatmayı kaldırmaya zorladığı şehzade Küçük Mustafa isyanıyla uğraşmak zorunda kaldı. II. Murad sonunda bu isyanı bastırmayı başarmış olsa da devletini büyük bir siyasî krize sokan bu gelişmeler, babası I. Mehmed'in idareyi iki büyük oğlu arasında paylaştırarak devleti zayıflatma ve iki küçük şehzadesini Bizans imparatorunun vesayetine verme pahasına Bizans imparatoru ile barış1 sürdürmek için neden büyük bir çaba sarfettiğini açıç̧a gözler önüne sermektedir.

\title{
Sonuç
}

1421 yılında Bizans ile Osmanlı tarafını tekrar karşı karşıya getiren gerçek nedenleri tespit edebilmek için I. Mehmed'in ölümünden önce oğullarını II. Manuil'in vesayetine vermeyi tercih etme nedenlerini dikkatlice düşünmemiz gerekmektedir. Görünen odur ki ölümüne yol açan beklenmedik kaza, Mehmed'i taht namzedi Murad ile diğer oğulları arasında bir başka çatışmanın ortaya çıkmasını önlemek için işe yarar bir çözüm bulmaya zorladı. Sultan, iktidarın sorunsuz şekilde Murad'a geçmesi yönündeki planının başarısının Bizans imparatorunun tarafsızlığını sağlamaya bağlı olduğunu hesaplamış olmalıdır. Bu planın ancak imparatorun iki genç şehzadesinin velayetini üstlenmeyi, Murad'ın Anadolu'da, Mustafa'nın ise Rumeli'de hâkim olmayı kabul ederek bağlanabileceği bir antlaşmayla başarılı olabileceğini de düşünmüş olmalıdır. I. Mehmed'in Bizans'ın yine de şehzadeleri kışkırtarak Osmanlı devletine karşı krizler yaratabileceğini düşünüp düşünmediği akla gelebilir. Anlaşıldığı üzere sultan, bu planının tüm olası sonuçlarının farkındaydı. Başka bir deyişle, bir Osmanlı tehdidi durumunda, Bizans'ın Osmanlı iç savaşları döneminden beri izlediği politikayı devreye sokabileceğininin tamamen bilincindeydi. Aslında tam da bu nedenle taraflar arasında mevcut olan ve iki deneyimli hükümdar tarafından yaratılan denge siyasetinin devamını sağlamak istiyordu. Ancak Mehmed'i bu planı düşünmeye sevk eden asıl sebep, Osmanlı Devleti'nin o sıradaki durumuydu. Çünkü tarihi araştırmalar yıllardır I. Mehmed'in tahta çıkışıyla devletin yeniden örgütlendiği ve Ankara savaşı nedeniyle durdurulan Balkanlar'daki Osmanlı yayılmasının önünde bir engel kalmadığı görüşünü tekrarlasa da Osmanlı Devleti'nin durumunun henüz tamamıyla istikrarlı olmadığ 1 açıktır. Çünkü sultanın da çok iyi bildiği üzere, Anadolu'daki Türk beylikleri varlıklarını sürdürüyordu ve Bayezid'in şehzadelerinin çatışmalarında önemli rol oynayacak kadar Osmanlı'nın iç işlerinde hâlâ kayda değer bir etkiye sahiptiler. Bu durum, Mehmed'i Bizanslılar ile Osmanlılar arasındaki hassas dengenin bozulmadığı, haleflerinin hiçbir zaman oyun dışında bırakılmayacağı ve devleti güvende tutacak şartlarda bir anlaşma yapmaya zorlamış, böylece Mehmed, Osmanlı Devleti'nin bekasını sağlamak için bu şekilde hareket etmiş olmalıdır. Sultan, bu planın, devleti Bizanslı ve Anadolu'daki Türk müttefiklerinin kışkırtacağı olası iç çatışmalardan kurtaracağını hesaplamış görünmektedir. İmparatorun şehzadelere vasi atanması başka bir gerçeği daha ortaya çıkarmıştı.

Sultan Mehmed, Osmanlı merkezî idaresinin otoritesini henüz tam anlamıyla güçlendirememişti. Bu nedenle küçük oğullarının Bizans vesayetine girmesini ve Türk beylerinin şehzadeleri etkileyerek taht kavgalarına neden olmaları ihtimalini ortadan kaldırmak istedi. Ayrıca Mehmed, vaktiyle "baba" olarak hitap ettiği Bizans imparatorunu karşı cepheye itmek yerine kendi tarafına çekmeye çalıştı. Ancak iki hükümdarın fevrî haleflerinin devreye girmesiyle bu plan hayata geçirilemedi. Diğer yandan II. Murad, iki küçük şehzadeyi teslim etmediğinde Bizans'in desteğini alan Düzmece Mustafa ve Küçük Mustafa isyanlarıla uğraşmak zorunda kald1 (1423).

1402-1423 yılları arasındaki şehzadeler arasında ya da âsî şehzadelerle idare arasında yaşanan çatışmalar Osmanlı sultanlarının dimağında derin izler bıraktı. Bu kötü hatıralar nedeniyle Osmanlı sultanları, tahtları üzerinde hak iddia eden şehzadeleri kendilerine karşı etkili bir şekilde destekleme politikasını uygulamaya koymamaları için uzun bir süre Bizans imparatorlarına

\author{
History Studies \\ www.historystudies.net
}


açıktan meydan okumaya cesaret edemediler. Nitekim daha sonraları, Düzmece Mustafa ve Küçük Mustafa'nın etkisiz hale getirilmesinin Osmanlı veraset sorununa son vermediği ortaya çıktı. Osmanlı sultanları, herkesçe kabul edilecek (hanedanın en yaşlı üyesinin tahta çıkmasını öngören ekberiyet ilkesine dayalı) bir veraset sisteminin ihdas edildiği 17. yüzyılın başlarına kadar Bizans ve Türk beyleri tarafından desteklenebilecek muhtemel taht müddeilerinin tehdidinin gölgesinde hüküm sürdüler. Diğer bir deyişle Halil İnalcık'ın da belirttiği gibi, " $I$. Bayezid'in halefleri arasında 1402'de başlayan Osmanlı iç savaşl, ancak Konstantinopolis'in fethinden sonra sona erdi." 135

Sultan II. Mehmed, zayıf şehzadeyi güçlü olana karşı ya da iktidardakine karşı desteklemeye dayalı bir politika izleyen Bizans'ın otoritesini sarsabilecek daimî bir tehdit oluşturduğunu çok iyi anlamıştı. Bizanslı tarihçi Kritovulos'un aktardığı üzere Konstantinopolis'in fethinden önce kendisini kenti kuşatmaya yönlendiren nedenler ile ilgili askerlerine yaptığı konuşma bunun ispatı

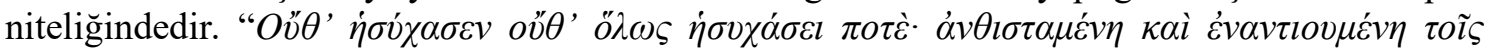

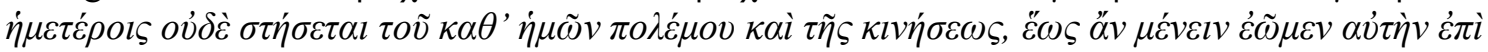

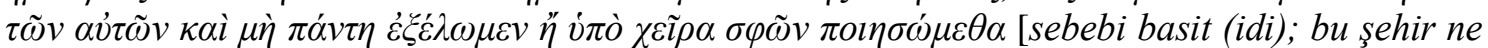
bize karşı isyan etmeyi ve ne de bizimkilere direnmeyi birakacaktır ve (bu şehrin), olduğu gibi kalmasına izin verdiğimiz ve (onu) tamamen yok etmediğimiz veya bizim yapmadiğımız sürece bize karşı savaşmayı ve tavır almayı bırakmayacaktır.]"136

\footnotetext{
${ }^{135}$ Halil İnalcık, “Ottoman Methods of Conquest”, Studia Islamica, C. II (1954), s. 103-106. 1444 yılında II. Mehmed tahta çıkar çıkmaz muhtemelen I. Bayezid'in oğlu Emir Süleyman'dan olan torunu olan şehzade Orhan'ın isyanıyla karşı karşıya kaldı. Bkz. Halil İnalcık, Fatih Devri üzerinde Tetkikler ve Vesikalar, C. I, Türk Tarih Kurumu Basımevi, Ankara 1954, s. 69-70; Dimitris Kastritsis, The Sons of Bayezid: Empire Building and Representation in the Ottoman Civil War of 1402-1413, Brill, Leiden 2007, s. 4, not. 11.

${ }^{136}$ Critobuli Imbriotae Historia, Ed. Diether D. Reinsch, Corpus Fontium Historiae Byzantinae, de Gruyter, Berlin 1983, s. 30.30-33.
} 


\section{KAYNAKÇA}

\section{Birinci El Kaynaklar}

Ahmad Ibn Arabshah, Tamerlane. The Life of the Great Amir, translated by J. H Sanders, Luzac and Co., London 1936.

Anonim Osmanlı Kroniği (1299-1512), Ed. Necdet Öztürk, Türk Dünyası Araştırmaları Vakfı, İstanbul 2000.

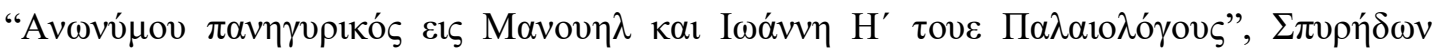

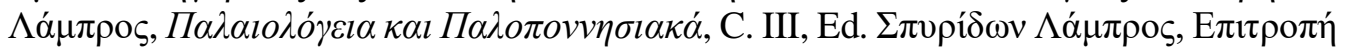

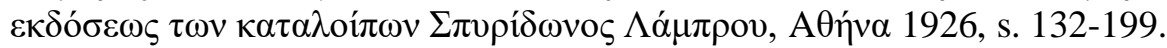

Âş1kpaşazâde, Tevarih-i Âl-i Osman, Âli Bey neşri, Matbaa-y1 Âmire, İstanbul 1332.

Critobuli Imbriotae Historia, Ed. Diether D. Reinsch, Corpus Fontium Historiae Byzantinae, de Gruyter, Berlin 1983.

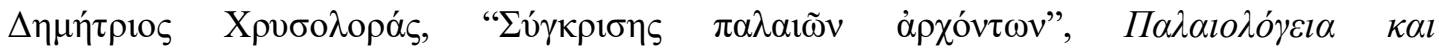

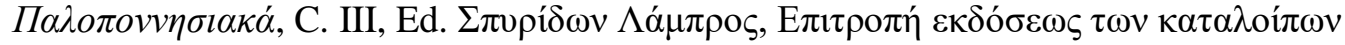

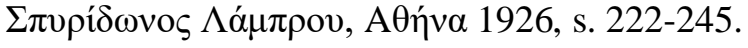

Diplomatarium Veneto-Levantinum sive Acta et Diplomata Res Venetas, Graecas atque Levantis Illustrantia, Ed. G. M. Thomas- R. Predeli, a. 1351-1454, C. II, Sumptibus Societatis, Venetia 1889.

Diplomatarium relationum Reipublicae Ragusanae cum regno Hungariae, Ed. Gelcich, Jozsef-Lajos Thalloczy, Magyar Tudományos Akadémia, Budapest 1887.

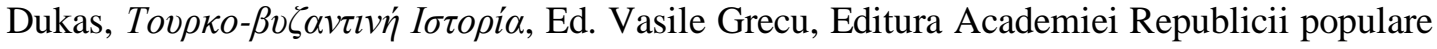
romîne (Scriptores byzantine 1), Bucuresti 1958.

Filozof Konstantin: Lebenschreibung des Despoten Stefan Lazarević von Kostantin dem Philosophen, Ed. Maximilien Braun, Mouton, Göttingen 1956.

Gazawat-ı Sultan Murad bin Mehemmed Han, İladi ve Varna Savaşları (1443-1444) Üzerinde Anonim Gazavatname, yay. Halil İnalc1k- Mevlüd Oğuz, Türk Tarih Kurumu Basımevi, Ankara 1989.

Georgios Sphrantzes, Chronicon Minus, Ed. Paul Migne, Patrologia Graeca, C. CLVI, Paris 1866, s.1025-1080.

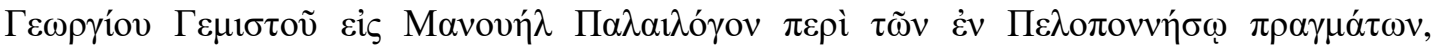

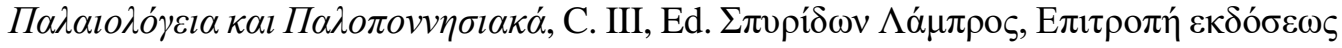

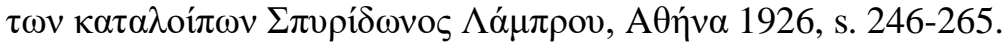

Hoca Sadeddin, Tacü't-tevarih, C. I-II, Ed. İsmet Parmaksızoğlu, Başbakanlık Kültür Müsteşerlığı Kültür Yayınları, İstanbul 1974.

Laonici Chalcocandylae Historiarum demonstrationes, Ed. Jenö Darkó, C. I-II, Editiones criticae scriptorum graecorum et romanorum, Budapest (1890 -) Budapest 1922-1927.

Lütfi Paşa, Tevarih-i Al-i Osman, Ed. M. Münir Aktepe, Türk Tarih Kurumu Yayınları, Ankara 1993.

Müneccimbaş1, Camiü'd-düvel, Osmanlı Tarihi (1299-1481), Ed. Ahmet Ağırakça, İnsan Yayınları, İstanbul 1995. 
Neşrî, Cihânnümâ, C. I-II, Ed. Faik Reşit Unat-Mehmed Altay Köymen, Türk Tarih Kurumu Basımevi, Ankara 1995.

Oeuvres de Ghillebert de Lannoy, Voyageur, Diplomate et Moraliste, Ed. H. Potvin, Louvain 1878.

Oruç b. Âdil, Tevârih-i Âl-i Osman, Ed. Franz Babinger, Hannover 1925.

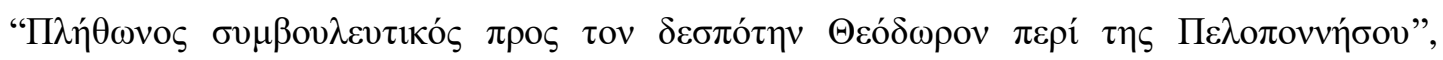

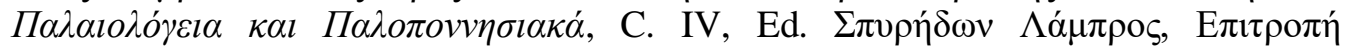

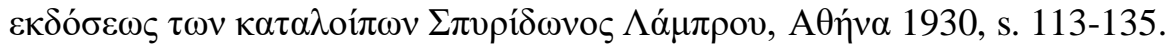

Pseudo-Ruhi, "Ruhî Tarîhi - Oxford nüshası", Ed. Yaşar Yücel - Halil Erdoğan Cengiz, Belgeler, C. XIV/18, (1989-1992)

Stefan Lazareviç, Yıldırım Bayezid'in Emrinde Bir Sirp Despotu, çev. Hüseyin Mevsim, İstanbul, Kitap Yayınevi, 2008.

Şikârî, Karamannâme [Zamanın kahramanı Karamanîler'in tarihi], Ed. Metin Sözen-Necdet Sakaoğlu, Karaman Valiliği- Karaman Belediyesi, İstanbul 2005.

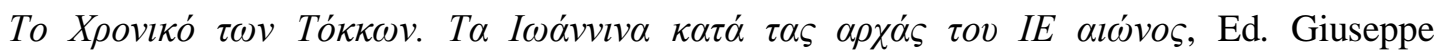

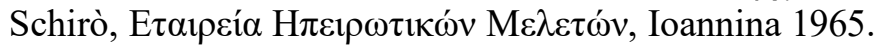

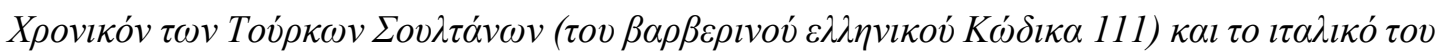

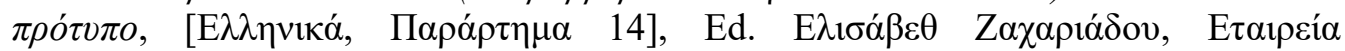

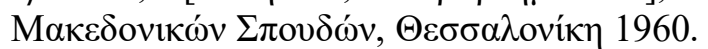

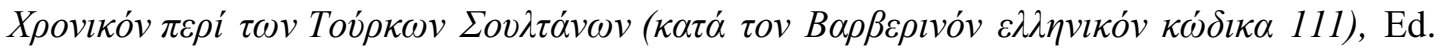

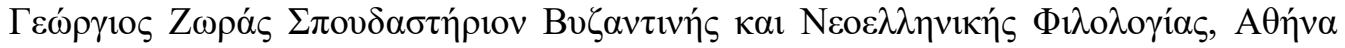
1958.

Modern Araştırmalar-İncelemeler

ALDERSON, Anthony Dolphin, The Structure of the Ottoman Dynasty, The Clarendon Press, Oxford 1956.

BALFOUR, David, Politico-historical works of Symeon. Politico-Historical Works of Symeon, Archbishop of Thessalonica (1416/17 to 1429), Österreichische Akademie der Wissenschaften, Vienna 1979.

BARKER, John, W., "On the Chronology of the Activities of Manuel II Palaeologus in the Peloponnesus in 1415" Byzantinische Zeitschrift, C. LV, München 1962, s. 39-55.

Manuel II Paleologus (1391-1425): A Study in Late Byzantine Statesmanship, Rutgers University Press, New Brunswick 1969.

DENNIS, George, The Letters of Manuel Palaeologus, Dumbarton Oaks Research Library and Collection, Washington 1977.

DIEHL, Charles, Figures byzantines, C. II, A. Colin, Paris 1908.

DJURIC, Ivan, Le Crépuscule de Byzance, Maisonneuve \& Larose, Paris 1996.

DÖLGER, Franz, "Die Krönung Johannes VIII. zum Mitkaiser," Byzantinische Zeitschrift, C. XXXVI, 1936, s. 318-319.

Regesten der Kaiserurkunden des oströmischen Reiches von 565-1453, C.

V, C. H. Beck, München 1965. 
ELAM, Nilgün, “Musa Çelebi’nin Rumeli’ye Geçişinde Hıristiyan Aktörlerin Rolü (14031410)", History Studies. International Journal of History Studies, C. III, S. 1 (2011), s. $83-111$.

EYİCE, Semavi “Anadolu Hisarı”, Türk Diyanet Vakfi İslam Ansiklopedisi, C. III (1991), s. 147-149.

FİLIPOVİČ, Nedim, Princ Musa i Sejh Bedreddin, Svjetlost, Sarajevo, 1971.

GILL, Joseph, "John VIII Palaeologus. A character study," Studi bizantini e neoellenici, C. IX, 1957, s.152-170.

HAMMER-PURGSTALL, Joseph, Geschichte des osmanischen Reiches, C. I, C. A. Hartleben, Pest 1833.

HEYWOOD, Colin J., «Küçük Mustafa», Encyclopedia of Islam, 2nd ed., C. VII, 1992, s.712713. 1992, s.710-712.

, «Mustafa Çelebi. Düzmece» Encyclopedia of Islam, 2nd ed. C. VII,

IMBER, Colin, The Ottoman Empire 1300-1481, İsis, İstanbul 1989.

İNALCIK Halil, "Ottoman Methods of Conquest," Studia Islamica, C. II, Paris 1954, s.103129.

Fatih Devri üzerinde Tetkikler ve Vesikalar, C. I, Türk Tarih Kurumu Basımevi, Ankara 1954.

, Halil, "Critica" Archivum Ottomanicum, C. III, 1971, s. 251-304.

, "The Ottoman Turks and the Crusades (1329-1451)", History of the Crusades, ed. Kenneth M. Setton, Madison-Wisconsin-London 1989, s. 222-310.

978. , “Mehemmed I" Encyclopedia of Islam, 2 ${ }^{\text {nd }}$ ed., C. VI, İstanbul 1991, s.973-

, “Murad II” İslam Ansiklopedisi, C. VIII, İstanbul 1997, s. 598-615.

, Devlet-i 'Aliyye, Osmanlı İmparatorluğu Üzerine Araştırmalar-I, İş Bankası Kültür Yayınları, İstanbul 2009.

Kuruluş Dönemi Osmanlı Sultanları, (1302-1481), İSAM Yayınları, İstanbul 2010.

JIRECEK, Constantine, Geschichte der Serben (1371-1537), c. II, F. A. Perthes, Gotha 1918, repr. Adolf M. Hakkert, 1967.

JORGA, Nicholae, Notes et Extraits pour servir à l'Histoire des Croisades au XVe siècle, C. I-IV, Ernest Leroux, Paris 1899-1902.

1900.

, Geschichte des Osmanischen Reiches, in Europa, C. I, Perthes, Gotha

KASTRITSIS, Dimitris, The Sons of Bayezid: Empire Building and Representation in the Ottoman Civil War of 1402-1413, Brill, Leiden 2007.

KHOURY, Théodore, «L'empereur Manuel II Paleologue», Proche Orient Chrétien, C. XV, 1965, s. 127-144. 
KILIÇ, Şahin, Bizans Kısa Kronikleri. Osmanlı Tarihinin Bizanslı Tanıkları (Ankara Üniversitesi, Sosyal Bilimler Enstitüsü Yayımlanmamış Doktora Tezi), Ankara 2011.

KIRLIDÖKME-MOLLAOĞLU, Ferhan, Selanik Basspiskoposu Symeon'un Tarihi Nutku (1387-1429)

The historical discourse of the archibishop of thessaloniki (Selanik) Symeon (13871429) (Ankara Üniversitesi Sosyal Bilimler Enstitüsü Yayımlanmamış Yüksek Lisans Tezi), Ankara 1998. Değerlendirilmesi (V.-VII. Bölümler), (Ankara Üniversitesi Sosyal Bilimler Enstitüsü, Yayımlanmamış Doktora Tezi), Ankara 2005.

KURAT, Akdes Nimet, Die türkische Prosopographie bei Laonikos Chalkokandyles, Neimann \& Moschinski, Hamburg 1933.

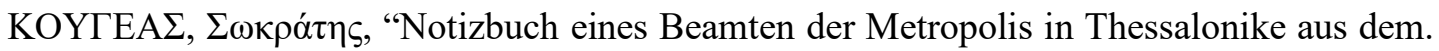
Anfang des XV. Jahrhundert," Byzantinische Zeitschrift, C. XXIII, 1919, München, s.143-163.

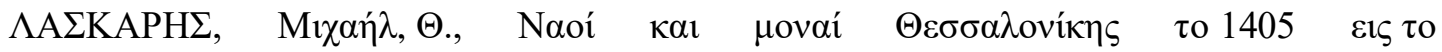

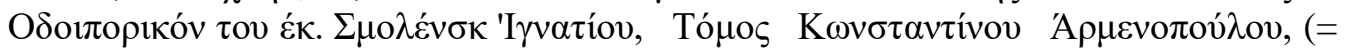

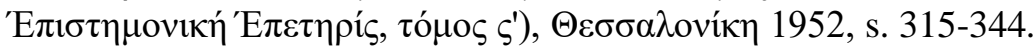

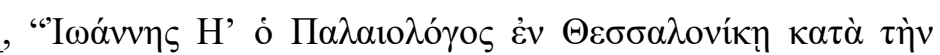

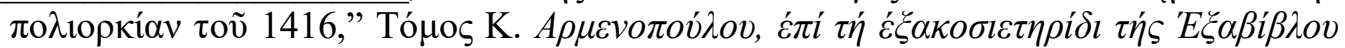

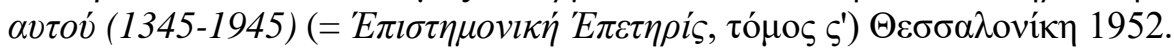

LOENERTZ, Raymond J., "Pour histoire du Peloponnese au XIVe siècle (1382-1404)," Revue des Etudes Byzantines, C. I, Paris 1943, s. 152-196.

"Autour du Chronicon majus attribué á Georges Sphrantzès," Miscelana G. Mercati, III, Rome 1946, s. 288-308.

, "Epître de Manuel II Paléologue aux moines David et Damien en 1416," Studi bizantini e neoellenici, C. IX, 1957, s. 294-304.

MATSCHKE, Klaus Peter, Die Schlacht bei Ankara und das Schicksal von Byzanz. Studien zur spätbyzantinischen Geschichte zwischen 1402 und 1422, Böhlau, Weimar 1981.

MELIKOFF, Irene, "Djunayd" Encyclopedia of Islam, $2^{\text {nd }}$ ed., C. II, Leiden 1991, s. 599-600.

MÉNAGE, Victor, Louise, “The Annals of Murad II," Bulletin of the School of Oriental and African Studies, C. XXXIX, 1976, s. 570-584.

$444-445$ , “Djandarli”, Encyclopedia of Islam, $2^{\text {nd }}$ ed., C. II, Leiden 1991, s.

MILLER, William, The Latins in the Levant. A History of Frankish Greece (1204-1566), John Murray, London 1908.

MORAVCSIK, Gyula, Byzantinoturcica, Sprachreste der Türkvölker in den byzantinischen Quellen, C. II, Kir. M. Pázmány Péter tudományegyetemi görög filológiai intézet, Budapest 1943.

NICOL, Donald M., The Last Centuries of Byzantium, Hart-Davis, London 1972. 
, Church and Society in the Last Centuries of Byzantium, Cambridge University Press, Cambridge 1979.

PEARS, Edwin, The Destruction of the Greek Empire and the Story of the Capture of Constantinople by the Turks, Longmans, Green and co., London 1903.

RUNCIMAN, Steven, The Fall of Constantinople 1453, Cambridge University Press, Cambridge 1965.

SCHREINER, Peter, Die byzantinischen Kleinkroniken, C. I-III, Österreichischen Akademie der Wissenschaften, Wien 1975, 1977, 1979.

SETTON, Kenneth M., The Papacy and the Levant (1204-1571) C. I-II, American Philosophical Society, Philadelphia 1976-1978.

STANOJEVIC, Stanoje, "Die Biographie Stefan Lazarević's von Konstantin dem Philosophen als Geschichtsquelle", Archiv für Slavische Philologie, C. XVIII, 1896, s. 409-72.

TAESCHNER, Franz, "Beiträge zur frühosmanischen Epigraphik und Archäologie", Der Islam, C. XX, 1932, s. 109-186.

, "The Ottoman Turks to 1453", Cambridge Medieval History, C. 4: The Byzantine Empire, Part 1: Byzantium and Its Neighbours, $2^{\text {nd }}$ ed., Cambridge University Press, Cambridge 1966, 753-775.

TURAN, Osman, İstanbul'un Fethinden Önce Yazılmış Tarihi Takvimler, Türk Tarih Kurumu Yayınları, Ankara 1984.

UZUNÇARŞILI, İsmail Hakkı, Osmanlı Tarihi, C. I, 5. Baskı, Türk Tarih Kurumu Yayınları, Ankara 1988. , "Mehmed I", İslam Ansiklopedisi, C. VII, İstanbul 1997, s.496-506.

THIRIET, Freddy, Regestes des deliberations du Senat de Venise concernant la Romanie (1400-1430), C. II, Mouton, Paris 1959.

VARLIK, Çetin, Germiyanoğulları Tarihi (1300-1429), Sevinç Matbaası, Ankara 1974.

WALTER, Gérard, La ruine de Byzance, 1204-1453, Albin Michel, Paris 1958.

WERNER, Ernst, Die Geburt einer Grossmacht--die Osmanen (1300-1481): Ein Beintrag zur Genesis des türkischen Feudalismus, Bohlau, Berlin 1966.

WITTEK, Paul, Das Fürstentum Menteshe, Studie zur Geschichte Westkleinasiens im 13.-15. Jh. Mit Dokumenten und Registern, Abteilung İstanbul des Archaologischen Institutes des Deutschen Reiches, Istanbul 1934.

WITTEK, Paul, Menteşe Beyliği 13- 15. Asırda Garbı Küçük Asya Tarihine Ait Tetkik, Çev: Orhan Şaik Gökyay, Türk Tarih Kurumu Yayınları, Ankara 1944 (Istanbuler Mitteilungen, İstanbul 1967).

ХРІгТОФІ

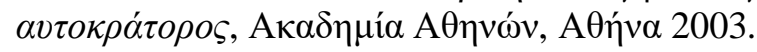

XIVREY, Jules Berger de, Mémoire sur la vie et les ouvrages de l'Empereur Manuel Paléologue, Imprimerie nationale, Paris 1851.

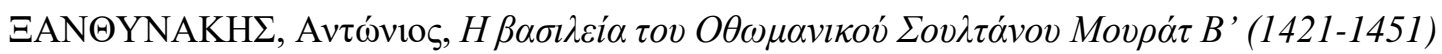

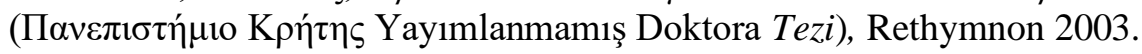


YÜCEL, Yaşar, XIII.-XV. Yüzyıllar Kuzey-Batı Anadolu tarihi. Çoban-oğulları Candaroğulları Beylikleri, Türk Tarih Kurumu Yayınları, Ankara 1980.

Trade and Crusade. Venetian Crete and the Emirates of Menteshe and Aydin (1300-1415), Instituto Ellenico, Venice 1983, s.83-89.

, "Ottoman Diplomacy and the Danube Frontier", HUS, Okeanos, Essays Presented to Ihor Sevcenko, C. VII, 1983, s.680-690.

ZAKYTHINOs, Dionysios A., Le despotat grec de Morée, C. I, Société d'édition "Les Belles Lettres," Paris, 1932, repr. Variorum, London 1975. 


\section{Summary}

The diplomatic contacts of Sultan Mehmed I (1413-1421) with the Byzantine emperor Manuel II Palaeologus (13911425 ) in his last years were of great importance as they aimed to ensure the survival of his state, which was not yet built on solid foundations, by keeping the peace between two parts. However, historians of the Ottoman palace are completely silent by not providing information about these contacts. On the other hand, Byzantine and Western historians give satisfactory information about the details of this theme.

Struggling to dominate both Anatolia and Rumelia, as before the Battle of Ankara (July 28, 1402), Mehmed I feared that the Byzantine emperor might play a role in a coordinated activity as an ally of Anatolian Turkish lords and Balkan Christian rulers if the Ottoman-Byzantine friendship broke down, as it was during the Ottoman Interregnum.

These powers, who would benefit greatly from the fragmentation and weakness of the Ottoman Empire, were Turkish chiefs such as Karamanoğlu Mehmed Beg II (?-1423) and Candaroğlu İsfendiyar Beg (1392-1440). The partners of the anti-Ottoman alliance group in the Balkans were Serbian despot Stefan Lazarevic and Vlah voivode Mircea. Chronicles of Byzantine historians such as Dukas, Sphrantzes, Halkokondyles, Kritoboulos, Anonymous Greek Short Chronicles, Manuel II's letters, Şikarî's Karamanname, the records of the Burgundian ambassador Ghillebert de Lannoy, the biography of Stephen Lazarevic by the Philosopher Konstantinos, the entries of the Venetian and Ragusan senate are eye-witnesses of this alliance.

The accession of Murad II on the Ottoman side and Ioannes VIII on the Byzantine side in 1421 destroyed the peace that Mehmed I and Manuel II had established by constructing it on delicate essentials. The young sultan had to face a series of revolts involving both the Byzantine emperor, who had turned into an enemy, and his allies in Anatolia and the Balkans, by disrupting the peace that his father tried to maintain by making significant concessions to the emperor.

The sources in question show that this alliance was not valid only during the Interregnum (1402-1413). They testify that the second "Pseudo" Mustafa rebellion, which broke out after Murad II's (1421-1451) accession to the throne, took action repeatedly with a common anti-Ottoman motive as a continuation of the first rebellion of Mustafa that broke out during the reign of Mehmed I.

Ottoman chronicles do not provide information about the connection between the power centers that came into play during these events, and present the military operations carried out by the sultans against this allied group as if they were independent events, unrelated to each other. In this respect, the testimonies of the above-mentioned sources gain great importance as they show that the developments in the Ottoman chronicles that forced the sultan to organize a campaign against the Anatolian principalities (which seem to be unrelated to each other) were actually a part of the joint operation of the anti-Ottoman group.

When the information given by Ottoman chronicler Âşıkpaşazâde that Murad blinded his two younger brothers and imprisoned them in Tokat and that he applied to Mihaloğlu Mehmed Bey to lure Rumelian begs back to his side against Mustafa, who provided the support of these elements, can only be matched with the data of the mentioned sources may be combined, it makes us able to see the overall picture.

This article aims to reconsider the role played by the Byzantine, Turkish and Balkan allies in the period of Ottoman history between the years of 1413 and 1423 in the light of all these sources.

\section{History Studies \\ www.historystudies.net}

